\title{
1 South Pacific Convergence Zone dynamics, variability, and impacts in a changing climate
}

2 Josephine R. Brown ${ }^{1}$, Matthieu Lengaigne ${ }^{2}$, Benjamin R. Lintner ${ }^{3}$, Matthew J. Widlansky ${ }^{4}$, 3 Karin van der Wiel ${ }^{5}$, Cyril Dutheil ${ }^{2,6}$, Braddock K. Linsley ${ }^{7}$, Adrian J. Matthews ${ }^{8}$ and James

$4 \quad$ Renwick $^{9}$

$5{ }^{1}$ School of Earth Sciences, University of Melbourne, Parkville, Victoria, Australia.

$6 \quad{ }^{2}$ LOCEAN, IPSL, CNRS/Sorbonne University/IRD/MNHN, Paris, France.

$7{ }^{3}$ Department of Environmental Sciences, Rutgers, The State University of New Jersey, New 8 Brunswick, New Jersey, USA.

$9{ }^{4}$ Joint Institute for Marine and Atmospheric Research, School of Ocean and Earth Science and 10 Technology, University of Hawai i at Mānoa, Honolulu, Hawaii, USA.

$11{ }^{5}$ Royal Netherlands Meteorological Institute, De Bilt, The Netherlands.

$12{ }^{6}$ IRD, Nouméa, New Caledonia, France.

$13{ }^{7}$ Lamont-Doherty Earth Observatory of Columbia University, Palisades, NY, USA.

$14{ }^{8}$ Centre for Ocean and Atmospheric Sciences, School of Environmental Sciences and School 15 of Mathematics, University of East Anglia, Norwich, United Kingdom.

$16{ }^{9}$ School of Geography, Environment and Earth Sciences, Victoria University of Wellington, 17 Wellington, New Zealand.

20 Corresponding author: Josephine Brown (josephine.brown@unimelb.edu.au) 


\section{Abstract}

22 The South Pacific Convergence Zone (SPCZ) is a band of intense rainfall and deep atmospheric convection extending from the equator to the subtropical South Pacific. The variability in rainfall, tropical cyclone activity, and sea level due to displacement of the SPCZ affects South Pacific Island populations and surrounding ecosystems. In this Review, we synthesize recent advances in understanding of the SPCZ in regards to the physical mechanisms responsible for its location and orientation, interactions with the principal modes of tropical climate variability, regional and global impacts, and response to human-induced climate change. These advances begin to provide a coherent description of its character and variability on synoptic, intraseasonal, interannual, and longer timescales. However, further efforts are needed to better assess and quantify the impact of the SPCZ on regional and global weather and atmospheric circulation. While current-generation climate models capture some aspects of SPCZ behavior, significant biases and deficiencies remain that limit confidence in future projections. Both improved climate model skill and new methods for regional modelling may better constrain future SPCZ projections, aiding adaptation and planning among vulnerable South Pacific communities.

\section{KEY POINTS}

- The South Pacific Convergence Zone is a major region of low-level wind convergence, convection and rainfall extending from the equator towards the southeast in the South Pacific, having a large impact on Pacific Island communities.

- The location and intensity of the SPCZ vary on timescales ranging from days to decades, as the SPCZ interacts with regional climate drivers such as the El NinoSouthern Oscillation. 
- Future changes in the SPCZ are uncertain, with climate models disagreeing on whether the SPCZ will become wetter or drier, highlighting the need to improve model reliability in this region.

\section{Introduction}

The South Pacific is the principal region on Earth where persistent deep convection of tropical origin often merges with the highly fluctuating mid-latitude storm track. These interactions result in a band of heavy rainfall extending southeastward from the Maritime Continent across the tropical and subtropical Pacific Ocean, known as the South Pacific Convergence Zone $(\mathrm{SPCZ})^{1-4}$. In observations, the SPCZ can be identified as a region of maximum rainfall (Fig. 1a) as well as minimum outgoing longwave radiation due to deep tropical convective clouds. Dynamically, this zone of intense convective activity is a result of low-level convergence between northeasterly trade winds (Fig. 1a), generated via anticyclonic flow around high pressure in the southeastern Pacific (Fig. 1b), and much weaker winds to the west ${ }^{4,5}$. The SPCZ is often considered to have two components: a zonally-oriented tropical rainfall band located over the western Pacific warm pool, and a diagonally-oriented (northwest to southeast) subtropical rainfall band that extends to approximately $30^{\circ} \mathrm{S}, 120^{\circ} \mathrm{W}$, with greatest extent

60 during austral summer (Fig. 1a). Alternatively, some studies identify equatorial, tropical and subtropical components of the $\mathrm{SPCZ}^{6}$ or break the diagonal SPCZ into two parts with a steeper slope in the eastern part ${ }^{7}$.

63 The atmospheric characteristics of the SPCZ are tightly coupled with the underlying pattern of 64 sea surface temperature (SST) (Fig. 1b), with the band of maximum rainfall located to the south of the latitude of maximum SSTs ${ }^{8,9}$. The tropical portion of the SPCZ lies over the western

66 Pacific warm pool (SST exceeding $28^{\circ} \mathrm{C}$ in present day climate ${ }^{10}$ ) where deep convection 
occurs often $^{11}$, while the subtropical portion of the SPCZ lies over somewhat cooler SSTs and is controlled by interactions with troughs in the mid-latitude circulation ${ }^{1,8}$.

Fluctuations in both atmospheric and oceanic circulations can cause large changes in the location, intensity, and extent of the SPCZ ${ }^{12,13}$. Within the SPCZ, rainfall varies on synoptic timescales (daily-to-weekly) and intraseasonal timescales (30 to 60-day fluctuations associated with the Madden-Julian Oscillation; MJO) ${ }^{14,15}$. On interannual, decadal, and longer timescales, the SPCZ also varies; for example, migrating meridionally and zonally in response to the El Niño-Southern Oscillation (ENSO) $)^{1,4,12}$ and Interdecadal Pacific Oscillation (IPO) ${ }^{16,17}$. As Earth's climate warms, changes in the mean state of the tropical Pacific may influence the SPCZ, for example altering its position or intensity ${ }^{18,19}$. A warmer climate may also lead to changes in SPCZ variability due to ENSO, such as an increase in the frequency of extreme El Niño events driving a large northward displacement of the SPCZ ${ }^{13}$.

Variability of the SPCZ is linked to changes in regional rainfall, tropical cyclone activity and sea level which affect the numerous and diverse island communities of the South Pacific. SPCZ variability also influences the global climate through the redistribution of convection and associated changes in atmospheric circulation patterns. Advances in observing and modeling the climate have greatly improved our physical understanding of the SPCZ, yet questions remain, especially regarding its impacts on regional and global-scale climate and its future evolution.

The last comprehensive review of the SPCZ, produced in $1994^{1}$, identified a number of unresolved questions regarding the SPCZ. These included the processes controlling the diagonal orientation of its subtropical component and its response to climate variability. Recent investigations of the SPCZ have benefited from a diverse array of new data sources including several decades of satellite observations ${ }^{7,20,21}$, atmosphere and ocean reanalysis datasets

91 providing retrospective descriptions over much of the $20^{\text {th }}$ century ${ }^{21-23}$, and paleoclimate proxy 
92 reconstructions of ocean temperature, salinity and rainfall derived from coral and speleothem

93 records ${ }^{24-27}$. As a result, there has been considerable improvement in our knowledge of the

94 mechanisms determining the SPCZ's diagonal orientation ${ }^{6,28-31}$, and its eastern boundary ${ }^{9,32,33}$

95 as well as the SPCZ's response to phenomenon such as the MJO, ENSO and the IPO ${ }^{12,16,28,34,35}$.

96 Studies of the mechanisms responsible for the origin of the SPCZ and its projected change

97 under future anthropogenic warming now utilize a hierarchy of numerical climate models,

98 including global coupled ocean-atmosphere models ${ }^{13,18,19,36-38}$, regional atmospheric

$99 \operatorname{models}^{39,40}$, and idealized or process-based models of the atmosphere ${ }^{30,31,33}$. These advances

100 have hence fostered a coherent perspective of the SPCZ spanning synoptic, intraseasonal,

101 interannual, and longer timescales, making an updated review of SPCZ research timely.

102 In this Review, we synthesize current understanding of the character of SPCZ, its variability 103 and impacts, and future projections. First, we outline proposed physical mechanisms

104 responsible for the SPCZ. Then we present the natural variability of the SPCZ from synoptic

105 to multi-decadal timescales, followed by a discussion of the regional and global climate

106 impacts of the SPCZ. The SPCZ response to future climate warming is then described. Finally,

107 we summarize current knowledge of the SPCZ and identify important questions for future 108 research. The ability of climate models to simulate the main features of the SPCZ is also 109 discussed (Box 1).

\section{2. The physical mechanisms of the SPCZ}

111 The existence of persistent regions of large-scale organized convection in the Southern

112 Hemisphere was first identified in early satellite images, with distinct bands of cloudiness

113 occurring in each of the major ocean basins ${ }^{2,3}$. These cloud bands, extending with a diagonal

114 orientation from the tropics to the subtropics, were found to be associated with widespread

115 convection and rainfall, as well as low level wind convergence. The most extensive band, 
116 named the South Pacific Convergence Zone ${ }^{4}$, is located in the South Pacific. Less intense bands

117 in the Atlantic and Indian Oceans are known as the South Atlantic Convergence Zone

$118(\mathrm{SACZ})^{3,41,42}$ and South Indian Convergence Zone (SICZ) ${ }^{43}$ respectively.

119 One of the most intriguing questions about the SPCZ (and the other Southern Hemisphere 120 convergence zones) is why convection is oriented diagonally southeast from the equatorial 121 region to the subtropics. In the following, we outline the main proposed mechanisms for the formation and diagonal orientation of the SPCZ. Broadly, these mechanisms consist of (1) transient bursts of diagonally-oriented convection triggered by Rossby waves ${ }^{6,28,29}$, (2) direct

124 forcing by tropical convection ${ }^{34,44}$, and (3) southwestward moisture advection from the eastern 125 Pacific dry zone ${ }^{9,32}$. The role of transient Rossby wave forcing is considered first.

126 The SPCZ has long been recognized as a region in which fronts or synoptic disturbances 127 moving from the southwest dissipate; for this reason, it has been referred to as a 'frontal 128 graveyard'4. A dynamical explanation for the SPCZ as frontal graveyard is provided by the strong zonal SST gradient in the subtropical Pacific, and associated trade wind and

130 convergence patterns, which generate a background flow that slows the passage of synoptic 131 disturbances originating from the mid-latitudes ${ }^{6}$. Model experiments with idealized SST configurations ${ }^{6}$ attribute the diagonal orientation of the SPCZ to accumulation of Rossby wave energy in regions of convergent zonal flow that form in response to the zonal SST gradient across the subtropical South Pacific.

135 Extending this framework, the location and orientation of SPCZ convection in the subtropics 136 has been further explained by Rossby wave energy accumulation ${ }^{28,29}$. During austral summer, 137 Rossby waves from the Southern Hemisphere subtropical jet refract ${ }^{1}$ (due to vorticity gradients

\footnotetext{
${ }^{1}$ Rossby waves are refracted in the atmosphere, just as light waves are refracted when passing through a medium with varying refractive index. The analogous refractive index for the atmosphere arises from the spatial distribution of vorticity in the background flow that the Rossby waves propagate in. Once the map of this refractive index has been calculated, ray paths for Rossby waves can then be constructed. It transpires that jet streams act as wave guides for Rossby waves, and regions of background easterly wind are 'forbidden' regions
} 
in the background flow) equatorward near New Zealand and thereby transit into the SPCZ

139 region ${ }^{29,45}$. The storm tracks are guided by the structure of the large-scale flow. Mean upper-

140 tropospheric easterly winds over the Indian Ocean and Maritime Continent 'forbid' Rossby

141 wave propagation, whereas mean upper-tropospheric westerly winds over the equatorial

142 Pacific (known as the 'westerly duct'46) 'allow' Rossby waves to propagate equatorward.

143 Disturbances in these waves acquire a diagonal orientation due to the combined effects of the

144 meridional shear of the zonal flow and wave refraction ${ }^{29}$, with the resultant diagonally

145 (northwest-southeast) elongated disturbances triggering convection along the $\mathrm{SPCZ}^{28}$. A

146 feedback between latent heat release from deep convection and associated vortex stretching

147 eventually leads to Rossby wave dissipation ${ }^{28-30}$ in the aforementioned frontal graveyard.

148 According to this mechanism, the chain of events that may lead to a diagonal SPCZ is

149 summarized in Fig. 2a. The trade winds, associated with the subtropical high in the lower-SST

150 southeastern Pacific, allow moisture to be transported southwestward into the SPCZ region. A

151 wave train ${ }^{2}$ from the subtropical jet is refracted towards the westerly duct in the equatorial

152 Pacific. Disturbances in these waves trigger convection and low-level convergence in a

153 diagonal band, where thermodynamic conditions and moisture are favorable for precipitating

154 deep convection to develop. Feedbacks between convection and circulation then act to halt

155 wave propagation and further dissipate the wave, typically within a day of convective

156 triggering. The timescale for this chain of events, from the initial wave train in the subtropical

157 jet to the burst of convection over the SPCZ is approximately five days. The climatological

\footnotetext{
for Rossby waves. As the background winds in the tropics are predominantly easterly, Rossby waves cannot generally propagate into the tropics, and therefore cannot generally pass from the Northern to the Southern Hemisphere, or vice versa. However, during austral summer a region of background westerly winds develops over the equatorial Pacific. This 'westerly duct' then allows Rossby waves to propagate into the tropics and pass from one hemisphere to the other. Further detail can be found in ref45 Hoskins, B. J. \& Ambrizzi, T. RossbyWave Propagation on a Realistic Longitudinally Varying Flow. J Atmos Sci 50, 1661-1671, doi:10.1175/15200469(1993)050<1661:Rwpoar>2.0.Co;2 (1993)..

2 The subtropical jet is a bountiful source region of wave trains, originating from baroclinic waves (typical midlatitude synoptic weather systems) to waves generated as the extratropical response to remote tropical convection.
} 
position of the diagonally-oriented eastern part of the SPCZ can therefore be viewed as the average of many such events occurring over the course of a season.

160 A second theory proposed to support the SPCZ diagonal orientation (shown in Fig. 2b) implies

161 a direct wave response to the localized steady tropical convective heating region over the

162 Maritime Continent ${ }^{34,44}$. This mechanism can account for some periods of SPCZ convective

163 activity although the largest fraction of SPCZ convection events are linked with the refraction 164 of transient Rossby wave trains as described above ${ }^{28}$. Nonetheless, the localized steady heating over the Maritime Continent is still a necessary ingredient, as the direct wave response to this leads to the existence of the westerly duct, which is necessary for the equatorward refraction

167 of midlatitude transient waves toward the SPCZ.A third proposed mechanism for the diagonal 168 orientation of the SPCZ focuses on the role of the eastern Pacific. The region to the east of the SPCZ is persistently free of deep convective rainfall year-round and has been referred to as the southeast Pacific 'dry zone' ${ }^{9}$. The forcing of this dry zone and its role in the maintenance of

171 the eastern edge of the SPCZ have been investigated ${ }^{9,32,33}$. A modeling study using an idealized 172 atmosphere coupled to an ocean mixed layer model ${ }^{9}$ demonstrated that the dry zone may 173 originate from orographic forcing from the Andes via a feedback involving subsidence, low clouds, and cooler SSTs. In this framework, the SPCZ acquires its diagonal tilt because of the orientation of the southeasterly trade wind flow. Thus, the eastern boundary of the deep convection in the SPCZ is set by the edge of the dry zone.

177 On shorter (1-5 day) timescales, periods of anomalous westerly winds over the southeast 178 Pacific result in a shift of the SPCZ eastern margin towards South America ${ }^{33}$. Viewed in terms 179 of the climatological distribution of moisture, the SPCZ exists in a region of a pronounced west-to-east moisture gradient. Considering the large-scale moisture budget, the trade wind

181 inflow into the SPCZ is directed from lower to higher mean moisture values, corresponding to 182 a drying term in the moisture budget. In this sense, a reduction in trade wind strength is 
associated with an anomalous moistening term. As studies have suggested the existence of a

184 critical moisture threshold for precipitating deep convection to occur ${ }^{47}$, reduced wind strength

185 is associated with increased convection and rainfall, which can be interpreted as a shift in the

186 eastern SPCZ margin.

187 The relative importance of the different surface boundary conditions necessary to support a

188 diagonal SPCZ has been investigated using atmospheric models forced with changes in the orography of the Andes, the location of continents, and altered SST patterns. Such an approach

190 is highly idealized, as coupled atmosphere-ocean processes are necessary to produce the SST

191 distribution, but can provide useful dynamical insights. In agreement with earlier studies ${ }^{8,48}$,

192 recent modelling results confirm that the configuration of continents and the presence of the

193 Andes have only a modest direct impact on the subtropical component of the $\mathrm{SPCZ}^{6,31}$ (that is,

194 the removal of the Andes or the South American continent, while leaving the zonal SST

195 gradient in the Pacific undisturbed, has minimal impact). These modelling studies find that the

196 primary requirement for the diagonal SPCZ is the zonal SST gradient in the subtropical South

197 Pacific, which reaches its seasonal maximum during austral summer. This leads to a strong

198 South Pacific high, which transports moist air from the equator to the SPCZ region (Fig. 2a).

199 Of course, the southeast Pacific dry zone and anticyclonic circulation also contribute to the

200 development of the zonal SST gradient. Thus, continental configuration and the presence of

201 orography exert an indirect impact on the SPCZ through their role in the setting of the boundary

202 conditions for the zonal SST gradient ${ }^{9}$.

\section{3. Natural variability of the SPCZ}

204 As outlined above, the SPCZ can be viewed as the sum of discrete pulses of convective activity

205 lasting several days. In this framework, low-frequency variability of the background state can modify the characteristics of such convective events ${ }^{6,28}$, resulting in SPCZ variability on 
intraseasonal to interdecadal timescales. Below we summarize the key features of SPCZ natural variability and its associated mechanisms based on observations, paleoclimate records, theory and dynamical models.

\subsection{Synoptic and intraseasonal timescales}

211 The Madden-Julian Oscillation (MJO) $)^{14,15}$ is an eastward-propagating equatorial mode of 212 planetary-scale convective anomalies on intraseasonal timescales (nominally 30-60 days).

213 Early satellite observations indicated that intense convection in the SPCZ region tends to be 214 out of phase with that in the Indian Ocean, but varying on similar intraseasonal timescales,

215 suggesting that the MJO modulates the SPCZ ${ }^{1}$. Analysis of an extended record of 30 years of 216 satellite data further identified the propagation of the MJO signal within the $\mathrm{SPCZ}^{7}$, with both 217 enhanced and suppressed convection evident during different phases of the MJO, as defined 218 by the standard Wheeler and Hendon MJO phase index ${ }^{49}$. As the MJO propagates eastward, 219 the region of enhanced SPCZ convective activity also moves eastward, with SPCZ anomalies 220 due to MJO activity as far south as $30^{\circ} \mathrm{S}^{7}$.

221 Detailed analysis of an MJO event reveals the poleward and eastward progression of 222 intraseasonal anomalies along the $\mathrm{SPCZ}^{34}$. The MJO modifies the basic state, thereby altering 223 the probability of occurrence of the two main modes of SPCZ variability: a westward shifted 224 SPCZ and an enhanced SPCZ ${ }^{28}$. Dynamically, the main influence of the MJO on the SPCZ is through its modulation of the shorter (five-day) timescale transient extratropical-tropical wave interaction events discussed in the previous section. When MJO convection is enhanced over

227 the eastern Indian Ocean and Maritime Continent (phases 3-6 using the standard MJO 228 indices $^{49}$ ), an equatorial Kelvin wave response produces westerly anomalies in the upper troposphere over the equatorial western Pacific. When combined with the mean flow, the effect is that the westerly wind duct expands toward the western Pacific. Consequently, extra-tropical

231 wave trains propagating eastward along the subtropical jet in the Southern Hemisphere refract 
equatorwards at more westward longitudes and thereby generate diagonally orientated convective events located west of the mean SPCZ position. Averaged over a period of several days, the mean SPCZ is observed to shift westward ${ }^{28}$.

\subsection{Seasonal timescales}

236 The seasonal cycle of insolation and SSTs drives the most prominent variations in the SPCZ.

237 The SPCZ is most fully developed in the austral summer (December to February), with greater

238 accumulated rainfall and larger spatial extent, as the conditions conducive for convection are strongly tied to the oceanic heat content and the zonal SST gradient that are maximized during that season. In particular, the necessary ingredients for the formation of the SPCZ (discussed in the previous section) are only consistently present during austral summer: the existence of the westerly wind duct to allow equatorward propagation of Rossby waves, and high SSTs in the southwest Pacific to fuel convection ${ }^{30,32}$.

The seasonal cycle of the SPCZ however differs in its tropical and subtropical portions, with the subtropical SPCZ being most active early in the austral warm season, around November to

246 December, while the tropical SPCZ is most active in January and February ${ }^{7}$. The tropical and

247 subtropical portions of the SPCZ are not always connected on sub-seasonal or seasonal 248 timescales, thus the December to February climatology represents the 'peak' of SPCZ activity, when the two portions align in a continuous region of convection ${ }^{7}$.

\subsection{Interannual timescales}

\subsubsection{Observed interannual variability}

252 Other than the seasonal cycle, the largest SPCZ variability is associated with ENSO, with a 253 characteristic timescale of $2-7$ years $^{4}$. Instrumental records, available from the late $19^{\text {th }}$ century 254 onwards, and satellite data from the 1960s onwards, provide a detailed picture of the observed SPCZ response to ENSO. Unlike the MJO, which is mostly associated with atmospheric 
variability, ENSO is characterized by substantial oceanic heat content changes in the Indo-

257 Pacific region as well as changes in the winds and convection in the atmosphere ${ }^{50}$. During El

258 Niño development, the eastern equatorial regions of the Pacific and Indian Oceans warm as the

259 western Pacific warm pool discharges heat. During the opposite phase of ENSO (La Niña),

260 heat is discharged poleward into off-equatorial regions of the Pacific, including poleward of

261 the climatological SPCZ position. Associated with the anomalous oceanic temperatures are

262 changes in the atmospheric zonal and meridional overturning circulations (the Walker and

263 Hadley cells, respectively $)^{51}$, which affects the organization of convective regions like the

264 SPCZ.

265 Based on satellite and instrumental data, early studies of the SPCZ's response to ENSO ${ }^{4,52,53}$

266 identified a displacement of the SPCZ from its climatological position (Fig. 3a): south and west

267 for positive Southern Oscillation (La Niña) events (Fig. 3b) and north and east for negative

268 Southern Oscillation (El Niño) events (Fig. 3c). During La Niña events, ENSO forcing of the

269 SPCZ can be interpreted via an analogous mechanism to the MJO modulation described above

270 (that is, convection is enhanced over the eastern Indian Ocean and Maritime Continent, which

271 induces a westward expansion of the westerly duct, westward shifted refraction of waves, and

272 a westward shift of the SPCZ position $)^{28}$. A somewhat opposite shift of the SPCZ towards the east occurs during El Niño events ${ }^{28}$.

274 Recent studies however revealed that the spatial response of the SPCZ to ENSO is more complex than a simple south-west (La Niña) or north-east (El Niño) displacement. During

276 particularly strong El Niño events, such as 1982/83, 1991/1992, 1997/98 ${ }^{12}$ and 2015/16 ${ }^{54}$,

277 characterized by an intense warming in the central and eastern Pacific, the SPCZ shifts close 278 to the equator (moving northwards by up to 10 degrees latitude) and its diagonal orientation collapses into a more zonal structure ${ }^{12,13}$ (Fig. 3d). These so-called 'zonal SPCZ' events are 
associated with a weak meridional (north-south) temperature gradient between the equatorial cold tongue and the climatological location of the SPCZ. ${ }^{12,13,55}$

282 Consideration of large-scale atmospheric divergent moist static energy (MSE) transport offers a two-dimensional (2D) energetics perspective on the mechanistic relationship between ENSO

284 and the $\mathrm{SPCZ}^{35}$. This perspective draws analogies to meridional ITCZ displacements experienced over both the seasonal cycle and under past climate regimes, when the ITCZ is observed to migrate in the direction of the anomalously warm hemisphere ${ }^{56-58}$, from which MSE export to the cooler hemisphere occurs. Such ITCZ shifts have been quantified in terms of simple scaling relationships between cross-equatorial atmospheric energy transport and ITCZ latitude.

290 Under El Niño conditions, the central and eastern equatorial Pacific is an anomalous source of 291 MSE, since the ocean warming there supplies energy to the atmosphere in the form of increased surface turbulent fluxes, particularly latent heating ${ }^{59}$. On the basis that rainfall in the SPCZ shifts spatially by an amount equal to the displacement of the zero line of the divergent MSE

294 flux (the so-called energy flux equator), the observed northeastward/equatorward SPCZ displacements experienced during El Niño are comparable to the shifts obtained from the 2D energetics framework. The 2D energetics framework further allows for diagnosis of component processes associated with SPCZ displacements during El Niño; for example, it appears that cloud-radiative feedback contributes a positive feedback to these displacements ${ }^{35}$.

\subsubsection{Paleoclimate records of interannual variability}

300 The limited availability of climate observations in the South Pacific before the mid-20 ${ }^{\text {th }}$ century 301 makes paleoclimate reconstructions from natural archives, such as corals and speleothems,

302 valuable tools to reconstruct past SPCZ variability. A key aspect of the SPCZ for paleoclimate analysis is its location near the southwestern Pacific oceanic 'salinity front' where high salinity 
subtropical waters meet low salinity waters beneath the SPCZ ${ }^{60,61}$. Information about both SST and surface ocean oxygen isotopic ratios, which reflect salinity, can be obtained from coral oxygen isotopic ratios (expressed as $\delta^{18} \mathrm{O}$ ) measured at near-monthly resolution and extending back several hundred years. Thus interannual variability in SST or salinity at the location of the SPCZ may be recorded in coral $\delta^{18} \mathrm{O}$ values. For example, interannual coral $\delta^{18} \mathrm{O}$ variability at several sites in the southwestern Pacific ${ }^{24,62,63}$ largely arises from advection of the oceanic 'salinity front' co-located near the subtropical terminus of the SPCZ in the southwestern

311 Pacific, which may reflect displacement of the SPCZ in response to ENSO.

312 A range of annually-resolved coral records from sites influenced by the SPCZ have been used 313 to investigate past variability of the SPCZ due to $\mathrm{ENSO}^{24,62-67}$. For instance, a coral $\delta^{18} \mathrm{O}$ series 314 generated from Ta'u Island in American Samoa provides a record of SST and salinity in a 315 location close to the SPCZ central rainfall axis extending back nearly 500 years (1521-2011

316 C.E. $)^{63,68}$. This coral series records an interannual phase shift in the late 1920s, indicating that

317 the current relationship whereby El Niño events lead to more saline conditions in this region 318 existed only back to this time ${ }^{68}$. Ta'u Island is situated in the current ENSO 'null' zone where 319 on average there is no correlation between interannual SST anomalies and those on the equator.

320 The record provides evidence that this ENSO null zone in the central SPCZ rainfall axis is not stationary but rather has shifted northeast and southwest in the past ${ }^{63}$.

322 Coral records also provide information about the sensitivity of the SPCZ variability to different 323 types of El Niño events ${ }^{26,62,63}$. For example, analysis of a 262 year (1742-2004 C.E.) coral 324 record of sea surface salinity from the Makassar Strait, the main channel of the Indonesian 325 Throughflow, shows that interannual changes in surface salinity in this region are intermittently related to zonal SPCZ events (when the SPCZ is rotated towards the equator during strong El

327 Niño events) ${ }^{26}$. During these events, stronger South Pacific boundary currents force high 328 salinity water through the Makassar strait and truncate the normal seasonal freshening. Based 
329 on this teleconnection, the Makassar coral $\delta^{18} \mathrm{O}$ data provide the first estimation of the

330 recurrence interval of zonal SPCZ events prior to 1979 and suggests that these events have

331 occurred on a semi-regular basis since at least the mid-1700s ${ }^{26}$.

\section{$332 \quad 3.4$ Interdecadal timescales}

\section{$333 \quad 3.4 .1$ Observed interdecadal variability}

334 Decadal-scale climate variability in the tropical Pacific is dominated by the IPO ${ }^{69}$ (and the 335 closely related Pacific Decadal Oscillation ${ }^{70}$ ). Resembling the ENSO SST spatial pattern but 336 with larger anomalies in the subtropics, the IPO is responsible for large decadal to multi-

337 decadal variations of the SPCZ location ${ }^{16,17,71}$. The SPCZ tends to move northeastward during 338 positive IPO phases, as during El Niño events, and southwestward during negative IPO phases, 339 as during La Niña events. While shifts in the position of the SPCZ due to ENSO and the IPO 340 have comparable magnitude, they operate quasi-independently ${ }^{16}$. IPO modulation of SPCZ 341 position is evident since the early 20th century ${ }^{23}$ as assessed from atmospheric reanalysis of 342 that period ${ }^{72}$. In addition, IPO-related variability of the SPCZ can make it difficult to identify 343 trends in observed rainfall in the South Pacific, as discussed in the next section.

\section{$344 \quad$ 3.4.2 Paleoclimate records of interdecadal variability}

345 As the instrumental records captures only a small sample of decadal variability, paleoclimate 346 records are invaluable for reconstructing SPCZ variability on interdecadal timescales. An index 347 of interdecadal South Pacific surface ocean variability developed from $\delta^{18} \mathrm{O}$ series from Porites 348 corals from Fiji and Tonga contains relatively stable interdecadal variability (with mean period $349 \sim 20$ years) back to the early $1600 \mathrm{~s}^{25}$, suggesting that the SPCZ position has experienced similar 350 interdecadal fluctuations for the past four centuries. However, another study using two 351 centuries of $\delta^{18} \mathrm{O}$ in Diploastrea coral from Fiji rather suggests that the character of these 352 interdecadal variations has changed over time, with larger variability from $\sim 1880$ to $1950^{73}$. 
353 Secular trends in SPCZ position were evaluated using Fiji and Rarotonga coral $\delta^{18} \mathrm{O}$ and $\mathrm{Sr} / \mathrm{Ca}$

354 (a temperature sensitive proxy), showing that the eastern extent of the SPCZ has shifted east355 west through $10^{\circ}$ to $20^{\circ}$ of longitude three times since the early $1600 \mathrm{~s}^{24}$. The largest shift began 356 in the mid-1800s as the salinity front moved progressively eastward, indicating a gradual 357 change to more La Niña-like mean conditions ${ }^{24}$. More recently, re-evaluation of the trends in 358 coral $\delta^{18} \mathrm{O}$ series from Fiji, Tonga and Rarotonga indicates that freshening began in the mid359 1800s in Fiji, but later at Tonga and Rarotonga ${ }^{62}$, The difference between the sites suggests 360 that the freshening trend does not simply reflect changes in the SPCZ character but rather is 361 primarily the result of changes in ocean circulation.

362 Speleothem records of the SPCZ have also been obtained from a number of Pacific Islands 363 including Vanuatu ${ }^{27}$, Solomon Islands ${ }^{74}$ and Niue ${ }^{75}$. A 446-year speleothem record from 364 Vanuatu ${ }^{27}$ shows evidence for decadal variability of the SPCZ. Decadal variability of the SPCZ was lowest in the instrumental period, with an overall trend towards wetter conditions during the past 100 years $^{27}$. A 600-year speleothem record from the Solomon Islands ${ }^{74}$ also captures movement of the SPCZ in response to Pacific decadal variability that persist over the entire record.

\section{Regional impacts of SPCZ variability}

370 The variability of the SPCZ on the timescales described above produces a wide range of climate impacts for the South Pacific region, which in turn have social and environmental impacts for the communities of the South Pacific Islands. Climate impacts of the SPCZ include changes in mean seasonal rainfall and rainfall extremes, changes in the location of tropical cyclone

374 formation and tracks, and sea level anomalies. In addition to impacts on the South Pacific,

375 SPCZ variability is associated with regional and global climate responses via atmospheric teleconnections. 


\subsection{Rainfall}

378

379

380

381

382

383

384

385

386

387

388

389

390

391

392

393

394

395

396

397

398

Many South Pacific island communities rely on rainfall for freshwater needs such as drinking water and agriculture and are thus extremely vulnerable to rainfall variations related to the position and intensity of the SPCZ ${ }^{76}$. Fluctuations of the SPCZ on interannual and decadal timescales may substantially increase or decrease seasonal mean rainfall totals for these islands $s^{60,76,77}$. SPCZ variability also influences daily rainfall extremes, which can trigger floods and droughts ${ }^{77-79}$. There is a strong influence of ENSO on total rainfall and rainfall extreme in the South Pacific through its control on the SPCZ location ${ }^{79}$ (Fig. 3). While islands located near the equator (for example, Nauru and Kiribati) and east of the SPCZ mean location (for example, Tahiti) generally experience an increase in mean and extreme rainfall during El Niño events, islands located in the southwest Pacific to the south of the SPCZ mean location (for example, Vanuatu, Fiji, Tonga and New Caledonia) experience drier conditions. Satellitemeasured historical rainfall records reveal large-scale interannual anomalies of over $\pm 50 \%$, particularly for the region around $\mathrm{Tahiti}^{80}$, which is especially vulnerable to heavy rainfall or droughts during strong El Niño (zonal SPCZ) and La Niña (more diagonal SPCZ), respectively.

The different types or 'flavors' of El Niño have distinct rainfall impacts in the South Pacific ${ }^{76}$. For instance, eastern Pacific El Niño events typically produce marked drying over southwest Pacific islands, while such drying is weaker during central Pacific El Niño events. This response stems from larger SPCZ northward excursions during eastern Pacific El Niño events compared to central Pacific events. Similarly, during strong El Niño events as in 1982/83 and 1997/98, Nauru and Tarawa (Kiribati) experienced dry conditions whereas these islands typically experience wetter than average conditions during El Niño years ${ }^{76}$. 


\subsection{Tropical cyclones}

400 Tropical cyclones (TCs) account for three quarters of the reported natural hazard disasters

401 within the Pacific ${ }^{81}$, with substantial socio-economic and ecological consequences for the 402 islands of the Southwest Pacific ${ }^{82}$. The SPCZ is the main TC genesis region in the South 403 Pacific $^{12,83,84}$. In general, TC genesis occurs in regions where four essential atmospheric 404 conditions exist ${ }^{85}$ : 1) sufficient thermodynamic energy, 2) abundant moisture, 3) low-level 405 cyclonic vorticity, and 4) minimal vertical wind shear. The environment along and up to $10^{\circ}$ 406 poleward of the main axis of the SPCZ exhibits these requirements during austral summer, the 407 peak of the regional TC season ${ }^{12}$. The importance of the SPCZ position in controlling the large408 scale atmospheric conditions favorable for TCs is also illustrated by considering the TC genesis 409 response to interannual variations of the SPCZ during El Niño and La Niña (Fig. 4a), which 410 shift TC occurrence to the northeast or southwest, respectively ${ }^{12,86-88}$. A northeastward shift of 411 the SPCZ induces a large decrease in cyclogenesis in the Coral Sea and near Fiji ( - 25\%) while 412 a southwestward shift of the SPCZ results in a large cyclogenesis decrease in the Tuvalu region $413(\sim-75 \%)$ and a more modest decrease in the Fiji region $(\sim+30 \%)^{12}$.

414 Recent research indicates that different types of El Niño events (warming focused in the eastern 415 or central equatorial Pacific, which affects the pattern of SST gradients and thus the 416 atmospheric circulation) have different impacts on SPCZ position and associated TC genesis 417 characteristics $^{12,89}$ (Fig. 4a). For example, TCs generally threaten Tahiti in the central South 418 Pacific only when the SPCZ displays a zonal orientation, which occurs mostly during strong 419 eastern Pacific El Niño events. During the extreme 1982/83 El Niño, Polynesia for instance 420 experienced the most active TCs season ever reported, with six tropical storms including the catastrophic Severe Tropical Cyclone Veena ${ }^{90}$. During 1997/1998, when another strong El Niño occurred, several TCs tracked as far east as near Tahiti ${ }^{12}$, including the especially deadly 423 Severe Tropical Cyclone Martin ${ }^{91}$. 
The South Pacific experiences substantial sea level variations on both seasonal and interannual timescales, predominantly due to wind-stress anomalies ${ }^{92}$, related largely to the position and intensity of the SPCZ, which drives strong wind-stress curl and related Ekman pumping signals in that region ${ }^{80}$. Similarly to the other climate impacts discussed, ENSO explains most of the interannual sea level variability in the SPCZ region.

430 During El Niño, weaker Pacific trade winds and negative wind-stress curl associated with a northeastward SPCZ shift induce a thermocline shoaling in the southwestern Pacific, causing the overlying sea surface height to concurrently lower ${ }^{80,93}$ (Fig. 4b). Sea levels can lower by 30 $\mathrm{cm}$ or more in the southwestern Pacific during strong El Niño events ${ }^{94}$, when zonal SPCZ events drive very strong wind-stress curl anomalies in that region ${ }^{80}$, thereby exposing shallow reefs and causing severe damage to associated coral ecosystems ${ }^{95}$ as well as intertidal zones such as mangrove forests ${ }^{96}$. The equatorward collapse of the SPCZ during strong El Niño events also induces an asymmetry in the sea level signature between the North and South Pacific, which prolongs below-normal sea levels (and associated ecological impacts) in the southwestern Pacific for several months after El Niño has ended ${ }^{80}$.

440 During La Niña, the SPCZ shifts southwest, the thermocline deepens in the southwestern

441 Pacific and the regional sea level rises (Fig. 4b). Above-normal sea levels during La Niña 442 (typically around $10 \mathrm{~cm}$ higher than the long-term average ${ }^{80}$ ) can exacerbate the coastal 443 flooding risk posed by ongoing global sea level rise, storms, as well as local land subsidence ${ }^{97}$ 444 that is occurring in parts of the SPCZ region such as around the Samoan Islands ${ }^{98,99}$.

\section{$445 \quad 4.4$ Remote teleconnections}

446 SPCZ variability not only exerts a local influence over the southwest Pacific but also remotely

447 influences regions in the tropics through atmospheric teleconnections. Shifts in SPCZ location, 
448 for instance, modulate rainfall over South America at both interannual ${ }^{100-102}$ and

449 intraseasonal ${ }^{103}$ timescales. On 30-60 day (MJO) timescales, anomalous convective activity in

450 the SACZ and SPCZ regions is dynamically connected, via Rossby wave propagation ${ }^{104,105}$.

451 Differences in ENSO impacts over South America in boreal spring have also been attributed

452 to SPCZ variability and the propagation of stationary Rossby waves from the South Pacific

453 into South America ${ }^{106}$.

454 The SPCZ also influences the climate of Southern Hemisphere high latitudes via atmospheric

455 teleconnections. One such teleconnection is with temperatures of West Antarctic and the

456 Antarctic Peninsula ${ }^{107}$. The variability of the SPCZ in early austral spring, especially on its

457 poleward side, is an important contributor to circulation and surface temperature trends across

458 the South Pacific, South Atlantic and West Antarctica. Increased deep convection along the

459 poleward edge of the SPCZ in September, driven by increased low-level wind convergence,

460 produces a Rossby wave train that propagates across the South Pacific to the South Atlantic ${ }^{107}$.

461 In addition, many of the climate shifts across West Antarctica during 2000-2014, when the

462 IPO was negative, can be explained by an SPCZ teleconnection with the Amundsen Sea

463 Low $^{108}$. 


\section{Climate change and the future of the SPCZ}

465 In addition to impacts due to natural variability discussed in the previous section, human466 induced global warming can potentially alter the SPCZ location, intensity and variability, 467 which would result in dramatic impacts on the climate of the South Pacific. A warming climate 468 is expected to lead to an enhanced hydrological cycle, with increased mean rainfall in tropical 469 convergence zones such as the $\mathrm{SPCZ}^{109,110}$ as well as altered rainfall patterns in response to 470 changes in SST gradients ${ }^{111,112}$. A warmer climate is also expected to lead to increases in 471 extreme rainfall events ${ }^{113}$ as well as amplified impacts of ENSO events ${ }^{114}$. We next examine 472 historical observations of the SPCZ and then projections based on climate model simulations 473 of a warmer future.

\section{$474 \quad 5.1$ Historical observations}

475 The most recent analysis of regional rainfall trends in the South Pacific ${ }^{115}$ indicates that trends over the past 70 years (1951-2015) are generally weak and not significant, except in southwestern French Polynesia and the southern subtropics, which both experienced declines in total (-53.4 and $-33.6 \mathrm{~mm} /$ decade respectively) as well as extreme rainfall. This contrasts with an earlier analysis of historical rainfall records from South Pacific islands for 1961-200077, which found multi-decadal trends with wetter conditions to the northeast of the SPCZ and drier to the southwest in response to an abrupt displacement of the diagonal section of the SPCZ in the late 1970s or early 1980s. The difference between the new and older analysis of SPCZregion rainfall trends can be attributed to the shift to a negative IPO phase around 1999. This suggests that South Pacific rainfall trends computed over relatively short periods ( 40 years) may arise from natural interdecadal variability ${ }^{71}$ rather than being a response to anthropogenic warming. 
487 The recent results pointing to weak historical trends in SPCZ rainfall are consistent with a study

488 of a sea level pressure-based index of SPCZ position ${ }^{116}$ demonstrating that the century-scale 489 trend from $1910 / 11$ to $2011 / 2012$ is small and not significant compared with the interannual 490 and interdecadal variability in SPCZ position. Thus the detection and attribution of observed 491 anthropogenic rainfall changes in the SPCZ region is hampered by the large natural multi492 decadal variability over the relatively short period of reliable observations.

\section{$493 \quad 5.2$ Projections from climate models}

494 Assessment of the SPCZ response to global warming relies heavily on climate projections 495 performed with coupled models such as those of the Coupled Model Intercomparison Project 496 (CMIP) ${ }^{117-119}$. Climate models are prescribed with a range of greenhouse gas concentrations 497 that are based on future emissions scenarios to produce projections of future climate, including 498 the SPCZ, which can be compared with model simulations of the historical period. The 499 representation of tropical Pacific climate ${ }^{120,121}$ and the $\mathrm{SPCZ}^{19}$ is slightly improved in the most 500 recent generation of CMIP coupled climate models (see Box 1). However, climate models still 501 exhibit long-standing biases, including an excessively cold equatorial cold tongue that extends 502 too far into the western Pacific ${ }^{122}$ and a tendency for the SPCZ to be too zonal and extend too 503 far eastward ${ }^{19,36}$, sometimes referred to as the 'double ITCZ' bias. Since the simulation of tropical rainfall and circulation is highly sensitive to the mean state of the tropical Pacific in

505 climate models ${ }^{111,112,123,124}$, the existence of model SST biases in this region limits the 506 reliability of future projections.

507 Climate models simulate a coherent tropical Pacific SST warming response to anthropogenic 508 forcing during the twenty-first century ${ }^{125,126}$, including a robust pattern of enhanced warming 509 in the equatorial Pacific ${ }^{127,128}$. Analysis of CMIP model simulations generally indicates no 510 consistent shift in SPCZ position in a warmer climate ${ }^{19,37}$, although most models do exhibit a 511 drying of up to $30 \%$ along the southeastern margin of the SPCZ (Fig. 5a). The drying is 
512 attributable to increased anomalous transport of dry subtropical air into the SPCZ region 513 associated with increased SST meridional gradients to the east ${ }^{18}$. Within the SPCZ core region,

514 two competing mechanisms largely explain the future uncertainty across models ${ }^{18}$ : warmer 515 tropical SSTs lead to increased atmospheric moisture and rainfall (the thermodynamic or 'wet 516 gets wetter' response; Fig. 5b), whereas weaker SST gradients reduce moisture convergence in 517 the SPCZ leading to drying (the dynamic or 'warmest gets wetter' response; Fig. 5c). The 518 amount of future warming, as well as the projected SST pattern, largely determines which 519 mechanism dominates, with a drier SPCZ more likely for moderate warming and a wetter 520 SPCZ more likely for greater warming (exceeding $3^{\circ} \mathrm{C}$ by the end of the century) ${ }^{18}$.

521 Recognition of systematic biases in global coupled models has motivated a range of alternative 522 approaches for simulating future changes in the SPCZ. Several studies have used atmospheric models forced with some form of bias-corrected SSTs ${ }^{18,39,40,123}$ or explored the use of regional models ${ }^{39,40}$. Atmosphere-only model simulations forced with SSTs consisting of the mean warming pattern from CMIP models added to the present-day observed climatology indicate that future drying of the SPCZ is a foreseeable possibility ${ }^{18,40}$, unlike the coupled-model mean projection of little change (see Fig. 5a). Projections from a set of regional atmospheric models 528 forced at their boundaries with outputs from global CMIP models ${ }^{39}$ exhibited a strong sensitivity to the choice of regional model, and some agreement on future drying of the SPCZ.

Another focus of research on future SPCZ projections is the possibility of changes in interannual variability, especially the occurrence of zonal SPCZ events that produce the most

532 severe climate impacts on the South Pacific. Despite an absence of consensus on how ENSO533 driven SST variability may change in the future ${ }^{114,125,126}$, a study based on a large ensemble of 534 climate model experiments ${ }^{13}$ reported a near doubling of zonal SPCZ event occurrence in the period 1991-2090 compared with 1891-1990. The increased occurrence of zonal SPCZ events over the twenty-first century stems from reduction of the South Pacific meridional SST 
537 gradient ${ }^{13,129}$, which facilitates equatorward displacement of the SPCZ. The increase in zonal 538 SPCZ events also drives a similar enhancement in El Niño-related sea level extremes in the

539 tropical southwestern Pacific ${ }^{94}$. In contrast with results based on CMIP models ${ }^{13}$, projections 540 using bias-corrected models did not find an increase in zonal SPCZ events in the future, even 541 with weakened meridional SST gradients $^{39,40,130}$.

\section{$542 \quad 6$. Summary and future perspectives}

543 Recent decades have seen an accumulation of studies contributing to an improved 544 understanding of the SPCZ, from its fundamental dynamics to its response to anthropogenic 545 climate change. Building on earlier work and making use of extended observational records, 546 satellite data, reanalyses and climate model experiments, we can begin to construct a 547 comprehensive description of the SPCZ which links its behavior on daily timescales to its 548 interannual and interdecadal variability and long term trends.

549 Studies of SPCZ dynamics have stimulated improved understanding of the main drivers responsible for the diagonal orientation of the subtropical SPCZ. However the respective contribution of main mechanisms (that is, transient bursts of diagonal convection triggered by Rossby waves, direct forcing by tropical convection and southwestward moisture advection

553 from the eastern Pacific dry zone) remains to be adequately quantified. The availability of new

554 or refined data sets may open additional pathways for research. For example, new atmospheric and oceanic reanalyses that begin early in the twentieth-century could be used to evaluate SPCZ variability prior to the satellite $\mathrm{er}^{23}$. As much of the SPCZ region remains poorly observed, both in the atmosphere and ocean, targeted field campaigns are needed. New observations could be used to study the interplay of dynamical mechanisms and thermodynamic processes

559 that affect the SPCZ. Specifically, aspects of the SPCZ such as the vertical distribution of diabatic heating, cloud radiative interactions, and air-sea interactions, would benefit from 
561 enhanced observations. One important focus is to clearly identify the main sources of moisture 562 for the SPCZ and how air masses are modified as they flow into and sustain rainfall in the 563 SPCZ.

564 Analysis of the natural variability of the SPCZ on interannual timescales has revealed an 565 unexpected complexity beyond a simple north/south or east/west displacement with ENSO 566 phases. Instead, studies have found that strong warming in the tropical eastern Pacific may 567 drive a dramatic northward relocation and rotation of the SPCZ, which causes its convection to merge with the ITCZ near the equator during so-called 'zonal SPCZ' events. Further work is needed to extend this analysis to fully assess the impact of different 'flavors' of El Niño 570 events (eastern Pacific versus central Pacific) ${ }^{131}$ on the SPCZ, as well as possible future 571 changes in the pattern or frequency of these events.

572 Additional paleoclimate records, such as corals and speleothems, may also help to extend understanding of SPCZ variability on interannual, interdecadal and longer timescales. New multi-proxy datasets are being developed which promise to provide valuable tools for reconstructing changes in the SPCZ in a range of past climates. These include the PAGES2K 576 database ${ }^{132}$ and other marine and continental proxy databases (such as Iso2K, CoralHyro2K, 577 SISAL and MARPA). Paleoclimate records of past rainfall, salinity and other variables relevant to the SPCZ may enable reconstructions of the response of the SPCZ to cold glacial conditions, or to changes in zonal or meridional temperature gradients in past climates. If past SPCZ 580 changes can be reconstructed with sufficient confidence, this provides a target for climate 581 model simulations ${ }^{133}$. Those models which are better able to simulate the SPCZ in past climates 582 may provide more robust future projections.

583 Reliable projections of future changes in the SPCZ are necessary to support climate adaptation in the South Pacific islands. Coupled climate models have long struggled to accurately simulate the SPCZ (see Box 1) and future projections of rainfall changes remain highly uncertain (Fig. 
5a). There is a need for long-term efforts to improve climate model representation of the Pacific oceanic and atmospheric mean state and ENSO variability ${ }^{134}$. Such improvements are a necessary condition for an improved simulation of the SPCZ, although model resolution, sophistication of model convection schemes, and representation of atmosphere-ocean

590 feedbacks may also play important roles. When robust regional projections are urgently

591 required, some form of model bias correction (atmospheric experiments forced with corrected SST or flux-adjusted climate simulations) may improve model projections in the shorter term ${ }^{40}$.

Much progress has been made towards understanding the SPCZ, yet some areas of uncertainty remain. Topics for future work include: seeking improved understanding of the relationship between the SPCZ and SST patterns; further investigation of the similarities and differences between the SPCZ and other diagonal convergence zones such the SACZ; and better description of the impact of the SPCZ on regional and global weather and climate with focus on improved forecasting capabilities. In order to prepare for future changes in South Pacific rainfall and sea level variability, tropical cyclone formation and other impacts of the SPCZ,

600 producing reliable climate projections has emerged as a critical need. Addressing these issues

601 will help to better understand a key aspect of the global climate system, as well as support building resilience in the South Pacific islands to future climate variability and change.

Text Box 1: How well do climate models simulate the SPCZ?

604 Climate models from the Coupled Model Intercomparison Project phase 5 (CMIP5 ${ }^{118}$ ) exhibit a similar level of skill to the prior generation of CMIP $3^{117}$ models, albeit with fewer extremely poor models ${ }^{19}$. The current generation of CMIP6 ${ }^{119}$ models show a similar modest incremental

607 improvement (see Fig. 6). Persistent model biases include an overly zonal SPCZ that extends 608 too far eastward in many models ${ }^{19,38,121}$ as well as a cold tongue that extends too far 609 westward ${ }^{122,128}$. The overly zonal nature of the western, tropical portion of the SPCZ can be 610 dynamically linked to the cold tongue $\operatorname{bias}^{38}$. The inter-model spread in the simulated SPCZ in 
611 current generation models does not occur only in coupled ocean-atmosphere models: model-

612 to-model differences in SPCZ orientation are reduced when using atmosphere-only models

613 with prescribed SSTs, but large differences in SPCZ rainfall intensity remain ${ }^{135}$.

614 The persistent cold tongue and zonal SPCZ biases in climate models can influence the

615 projection of future changes in the SPCZ. In particular, the cold tongue bias may induce

616 unrealistic changes in rainfall in response to warming ${ }^{128}$. Mean state biases can also alter the

617 pattern of SST change ${ }^{40,123}$. However, despite the presence of biases, many CMIP5 models

618 produce a realistic north-east and south-west displacement of the SPCZ in response to El Niño

619 and La Niña events ${ }^{19}$. A smaller subset of models also captures the extreme 'zonal SPCZ'

620 events ${ }^{13,55}$, although future changes in frequency of such events are dependent on the modelling

621 configuration used ${ }^{13,40}$. Model evaluation has further demonstrated that CMIP5 models

622 plausibly simulate the interaction between large-scale circulation, moisture, and rainfall in the

623 eastern SPCZ region, indicating that the dynamic and thermodynamic processes responsible

624 for the large-scale circulation-moisture-rainfall relationship are reasonably simulated in these

625 models ${ }^{136}$. 
627 Figure 1: Climatology of the South Pacific. December to February a CMAP ${ }^{137}$ precipitation 628 (mm/day, colors) and NCEP2 $2^{138} 925 \mathrm{hPa}$ winds (m/s, vectors), and b ERSSTv5 ${ }^{139}$ sea surface 629 temperature $\left({ }^{\circ} \mathrm{C}\right.$, colors) and $\mathrm{NCEP} 22^{138}$ mean sea level pressure (hPa, contour lines) averaged 630 over 1980-2005.

631 Figure 2: Mechanisms for formation of the diagonal SPCZ. (a) Extratropical-tropical 632 interaction: the zonally asymmetric SST distribution generates a subtropical anticyclone over 633 the southeast Pacific, which results in southwestward moisture transport into the SPCZ region. 634 Dynamical forcing from equatorward propagating Rossby waves triggers convection in a northwest-southeast oriented band forming the diagonal SPCZ. Moisture is supplied at low levels from surface evaporation and advection around the eastern Pacific subtropical high [Adapted from refs. ${ }^{29,31}$. (b) Direct forcing by tropical convection: convection over the Maritime Continent forces an equatorial Rossby wave response with an upper-tropospheric anticyclone. On its eastern flank, this advects large magnitude potential vorticity (PV) equatorward, from the PV reservoir associated with the subtropical jet. The PV anomaly destabilises the atmosphere and leads to deep convection along the SPCZ [Adapted from 642 refs. ${ }^{34,44}$ ].

Figure 3: Displacement of the SPCZ in response to ENSO. Mean December to February 644 SPCZ position in: a all years, $\mathbf{b}$ La Niña years, $\mathbf{c}$ weak to moderate El Niño years, and $\mathbf{d}$ strong 645 El Niño years (1979-2018) using CMAP $^{137}$ precipitation and NINO3 SST from ERSSTv5 ${ }^{139}$ to 646 classify events. Weak-moderate El Niño is NINO3 greater than 0.5 standard deviations and 647 less than 1.5 standard deviations, La Niña is NINO3 less than -0.5 standard deviations, strong 648 El Niño is NINO3 greater than 1.5 standard deviations. SPCZ line (yellow) is fitted to the 649 latitude of maximum precipitation at each longitude in the range $155^{\circ} \mathrm{E}-150^{\circ} \mathrm{W}$ and $0-30^{\circ} \mathrm{S}$. 650 Red dashed line in b-d is all year average SPCZ position shown in a. Contour lines in b-d are rainfall anomaly relative to all year average (levels $=-4,-2,-1,1,2$ and $4 \mathrm{~mm} /$ day with negative values as dashed lines). a The linear regression of the tropical cyclone annual track density (July-June averages) from the IBTrACS ${ }^{140}$ observational dataset onto the average November-April seasonal Oceanic Nino Index (ONI) during 1979-2016. The tropical cyclone track density is normalized over the 
map domain for each year. Tracks during extreme El Niño seasons (corresponding to zonal

658 SPCZ events: 1982/83, 1991/92, 1997/98, and 2015/16) are shown in green. b Satellite and 659 tide-gauge measured sea level variability from the CMEMS dataset ${ }^{141}$ and Joint Archive for 660 Sea Level holdings ${ }^{142}$, contour and circle shadings respectively. The linear regression of 661 November-April sea level anomalies onto the seasonal ONI during 1994-2016 is shown 662 (shading). The average sea level anomaly during 1997/98 and 2015/16 is indicated by the blue $663(-10 \mathrm{~cm})$ and red $(10 \mathrm{~cm})$ contours.

664 Figure 5: Future change of the SPCZ. a The multi-model rainfall projection from 36 CMIP5 665 models for the RCP8.5 $\mathrm{W} \mathrm{m}^{-2}$ greenhouse warming scenario during 2075-2100 compared to 666 the historical simulation during 1980-2005. Changes are expressed as percentages compared 667 to the historical rainfall in CMIP5. Stippling indicates regions where less than 2/3 of models 668 agree on the sign of future change (larger circles) or future change is less than $\pm 1 \mathrm{~mm} \mathrm{day}^{-1}$ 669 (smaller diamonds). The $5 \mathrm{~mm} \mathrm{day}^{-1}$ contours of mean rainfall observed (blue; $\mathrm{GPCP}^{143}$ dataset 670 during 1980-2005) and simulated (magenta; CMIP5 historical during 1980-2005) are outlined. $671 \mathbf{b}$ and $\mathbf{c}$ Illustrations of the thermodynamic (wet gets wetter) and dynamic (warmest gets wetter) 672 mechanisms affecting the SPCZ rainfall response to greenhouse warming (adapted from ref. ${ }^{18}$ ). 673 Green and brown arrows indicate a tendency for increased or decreased rainfall, respectively, 674 associated with either mechanism. Conditions during DJF are shown in all panels.

675 Figure 6: How well do climate models simulate the SPCZ? DJF seasonal average rainfall 676 (mm/day) for 1980-1999 for a CMAP ${ }^{137}$ observations, b CMIP3 ${ }^{117}$ Multi-Model Mean 677 (MMM) (24 models), c CMIP5 ${ }^{118}$ MMM (26 models) and d CMIP6 ${ }^{119}$ MMM (27 models). 678 SPCZ line is fitted to the latitude of maximum precipitation at each longitude in the range $679155^{\circ} \mathrm{E}-140^{\circ} \mathrm{W}$ and $0-30^{\circ} \mathrm{S}$. The slope $\left(s,{ }^{\circ} \mathrm{S} /{ }^{\circ} \mathrm{E}\right)$ and mean latitude $\left(\right.$ lat,$\left.{ }^{\circ} \mathrm{S}\right)$ of the SPCZ line are 680 shown at upper right of each plot. 
6831 Vincent, D. G. The South-Pacific Convergence Zone (SPCZ) - A Review. Mon

2 Hubert, L. F. Subtropical Convergence Line of South Pacific - Case Study Using Meteorological Satellite Data. J Geophys Res 66, 797-\&, doi:10.1029/JZ066i003p00797 (1961).

3 Streten, N. A. Some Characteristics of Satellite-Observed Bands of Persistent Cloudiness over Southern Hemisphere. Mon Weather Rev 101, 486-495, doi:Doi 10.1175/1520-0493(1973)101<0486:Scosbo>2.3.Co;2 (1973).

4 Trenberth, K. E. Spatial and temporal variations of Southern Oscillation. Q J Roy Meteor Soc 102, 639-653, doi:10.1002/qj.49710243310 (1976).

5 Streten, N. A. \& Zillman, J. W. in World Survey of Climatology (ed H. van Loon) Ch. Climate of the South Pacific Ocean, 263-275 (Elsevier, 1984).

6 Widlansky, M. J., Webster, P. J. \& Hoyos, C. D. On the location and orientation of the South Pacific Convergence Zone. Clim Dynam 36, 561-578, doi:10.1007/s00382010-0871-6 (2011).

$7 \quad$ Haffke, C. \& Magnusdottir, G. The South Pacific Convergence Zone in three decades of satellite images. J Geophys Res-Atmos 118, 10839-10849, doi:10.1002/jgrd.50838 (2013).

8 Kiladis, G. N., Von Storch, H. \& Van Loon, H. Origin of the South Pacific Convergence Zone. J Climate 2, 1185-1195, doi:10.1175/15200442(1989)002<1185:Ootspc>2.0.Co;2 (1989).

9 Takahashi, K. \& Battisti, D. S. Processes controlling the mean tropical pacific precipitation pattern. Part II: The SPCZ and the southeast pacific dry zone. J Climate 20, 5696-5706, doi:10.1175/2007jcli1656.1 (2007).

10 Hoyos, C. D. \& Webster, P. J. Evolution and modulation of tropical heating from the last glacial maximum through the twenty-first century. Clim Dynam 38, 1501-1519, doi:10.1007/s00382-011-1181-3 (2012).

11 Johnson, N. C. \& Xie, S. P. Changes in the sea surface temperature threshold for tropical convection. Nat Geosci 3, 842-845, doi:10.1038/Ngeo1008 (2010).

12 Vincent, E. M. et al. Interannual variability of the South Pacific Convergence Zone and implications for tropical cyclone genesis. Clim Dynam 36, 1881-1896, doi:10.1007/s00382-009-0716-3 (2011).

13 Cai, W. J. et al. More extreme swings of the South Pacific convergence zone due to greenhouse warming. Nature 488, 365-369, doi:10.1038/nature11358 (2012).

14 Madden, R. A. \& Julian, P. R. Detection of a 40-50 Day Oscillation in Zonal Wind in Tropical Pacific. J Atmos Sci 28, 702-708, doi:10.1175/15200469(1971)028<0702:Doadoi>2.0.Co;2 (1971).

15 Madden, R. A. \& Julian, P. R. Description of Global-Scale Circulation Cells in Tropics with a 40-50 Day Period. J Atmos Sci 29, 1109-1123, doi:10.1175/15200469(1972)029<1109:Dogscc>2.0.Co;2 (1972).

16 Folland, C. K., Renwick, J. A., Salinger, M. J. \& Mullan, A. B. Relative influences of the Interdecadal Pacific Oscillation and ENSO on the South Pacific Convergence Zone. Geophys Res Lett 29, doi:10.1029/2001g1014201 (2002).

17 Salinger, M. J., Renwick, J. A. \& Mullan, A. B. Interdecadal Pacific Oscillation and South Pacific climate. Int J Climatol 21, 1705-1721, doi:10.1002/joc.691 (2001).

18 Widlansky, M. J. et al. Changes in South Pacific rainfall bands in a warming climate. Nat Clim Change 3, 417-423, doi:10.1038/Nclimate1726 (2013). 
19 Brown, J. R., Moise, A. F. \& Colman, R. A. The South Pacific Convergence Zone in CMIP5 simulations of historical and future climate. Clim Dynam 41, 2179-2197, doi:10.1007/s00382-012-1591-x (2013).

20 Haffke, C. \& Magnusdottir, G. Diurnal cycle of the South Pacific Convergence Zone in 30 years of satellite images. J Geophys Res-Atmos 120, 9059-9070, doi:10.1002/2015jd023436 (2015).

21 Kidwell, A., Lee, T., Jo, Y. H. \& Yan, X. H. Characterization of the Variability of the South Pacific Convergence Zone Using Satellite and Reanalysis Wind Products. $J$ Climate 29, 1717-1732, doi:10.1175/Jcli-D-15-0536.1 (2016).

22 Zuo, H., Balmaseda, M. A. \& Mogensen, K. The new eddy-permitting ORAP5 ocean reanalysis: description, evaluation and uncertainties in climate signals. Clim Dynam 49, 791-811, doi:10.1007/s00382-015-2675-1 (2017).

23 Harvey, T., Renwick, J. A., Lorrey, A. M. \& Ngari, A. The Representation of the South Pacific Convergence Zone in the Twentieth Century Reanalysis. Mon Weather Rev 147, 841-851, doi:10.1175/Mwr-D-18-0237.1 (2019).

24 Linsley, B. K. et al. Tracking the extent of the South Pacific Convergence Zone since the early 1600s. Geochem Geophy Geosy 7, doi:10.1029/2005gc001115 (2006).

25 Linsley, B. K., Zhang, P. P., Kaplan, A., Howe, S. S. \& Wellington, G. M. Interdecadal-decadal climate variability from multicoral oxygen isotope records in the South Pacific Convergence Zone region since 1650 A.D. Paleoceanography 23, doi:10.1029/2007pa001539 (2008).

26 Linsley, B. K. et al. SPCZ zonal events and downstream influence on surface ocean conditions in the Indonesian Throughflow region. Geophys Res Lett 44, 293-303, doi:10.1002/2016g1070985 (2017).

27 Partin, J. W. et al. Multidecadal rainfall variability in South Pacific Convergence Zone as revealed by stalagmite geochemistry. Geology 41, 1143-1146, doi:10.1130/G34718.1 (2013).

28 Matthews, A. J. A multiscale framework for the origin and variability of the South Pacific Convergence Zone. Q J Roy Meteor Soc 138, 1165-1178, doi:10.1002/qj.1870 (2012).

29 van der Wiel, K., Matthews, A. J., Stevens, D. P. \& Joshi, M. M. A dynamical framework for the origin of the diagonal South Pacific and South Atlantic Convergence Zones. Q J Roy Meteor Soc 141, 1997-2010, doi:10.1002/qj.2508 (2015).

30 van der Wiel, K., Matthews, A. J., Joshi, M. M. \& Stevens, D. P. The influence of diabatic heating in the South Pacific Convergence Zone on Rossby wave propagation and the mean flow. $Q$ J Roy Meteor Soc 142, 901-910, doi:10.1002/qj.2692 (2016).

31 van der Wiel, K., Matthews, A. J., Joshi, M. M. \& Stevens, D. P. Why the South Pacific Convergence Zone is diagonal. Clim Dynam 46, 1683-1698, doi:10.1007/s00382-015-2668-0 (2016).

32 Takahashi, K. \& Battisti, D. S. Processes controlling the mean tropical pacific precipitation pattern. Part I: The Andes and the eastern Pacific ITCZ. J Climate 20, 3434-3451, doi:10.1175/Jcli4198.1 (2007).

33 Lintner, B. R. \& Neelin, J. D. Eastern margin variability of the South Pacific Convergence Zone. Geophys Res Lett 35, doi:10.1029/2008g1034298 (2008).

34 Matthews, A. J., Hoskins, B. J., Slingo, J. M. \& Blackburn, M. Development of convection along the SPCZ within a Madden-Julian oscillation. $Q J$ Roy Meteor Soc 122, 669-688 (1996). 
35 Lintner, B. R. \& Boos, W. R. Using Atmospheric Energy Transport to Quantitatively Constrain South Pacific Convergence Zone Shifts during ENSO. J Climate 32, 18391855, doi:10.1175/Jcli-D-18-0151.1 (2019).

36 Brown, J. R. et al. Evaluation of the South Pacific Convergence Zone in IPCC AR4 Climate Model Simulations of the Twentieth Century. J Climate 24, 1565-1582, doi:10.1175/2010jcli3942.1 (2011).

37 Brown, J. R., Moise, A. F. \& Delage, F. P. Changes in the South Pacific Convergence Zone in IPCC AR4 future climate projections. Clim Dynam 39, 1-19, doi:10.1007/s00382-011-1192-0 (2012).

38 Niznik, M. J., Lintner, B. R., Matthews, A. J. \& Widlansky, M. J. The Role of Tropical-Extratropical Interaction and Synoptic Variability in Maintaining the South Pacific Convergence Zone in CMIP5 Models. J Climate 28, 3353-3374, doi:10.1175/Jcli-D-14-00527.1 (2015).

39 Evans, J. P., Bormann, K., Katzfey, J., Dean, S. \& Arritt, R. Regional climate model projections of the South Pacific Convergence Zone. Clim Dynam 47, 817-829, doi:10.1007/s00382-015-2873-x (2016).

40 Dutheil, C. et al. Impact of surface temperature biases on climate change projections of the South Pacific Convergence Zone. Clim Dynam 53, 3197-3219, doi:10.1007/s00382-019-04692-6 (2019).

41 Kodama, Y. Large-Scale Common Features of Subtropical Precipitation Zones (the Baiu Frontal Zone, the SPCZ, and the SACZ). Part 1: Characteristics of Subtropical Frontal Zones. J Meteorol Soc Jpn 70, 813-836, doi:10.2151/jmsj1965.70.4_813 (1992).

42 Kodama, Y. M. Large-Scale Common Features of Subtropical Convergence Zones (the Baiu Frontal Zone, the SPCZ, and the SACZ). Part II: Conditions of the Circulations for Generating the STCZs. J Meteorol Soc Jpn 71, 581-610, doi:10.2151/jmsj1965.71.5_581 (1993).

43 Cook, K. H. The South Indian convergence zone and interannual rainfall variability over southern Africa. J Climate 13, 3789-3804 (2000).

44 Kodama, Y. M. Roles of the atmospheric heat sources in maintaining the subtropical convergence zones: An aqua-planet GCM study. J Atmos Sci 56, 4032-4049, doi:Doi 10.1175/1520-0469(1999)056<4032:Rotahs>2.0.Co;2 (1999).

45 Hoskins, B. J. \& Ambrizzi, T. Rossby-Wave Propagation on a Realistic Longitudinally Varying Flow. J Atmos Sci 50, 1661-1671, doi:10.1175/15200469(1993)050<1661:Rwpoar>2.0.Co;2 (1993).

46 Webster, P. J. \& Holton, J. R. Cross-Equatorial Response to Middle-Latitude Forcing in a Zonally Varying Basic State. J Atmos Sci 39, 722-733, doi:10.1175/15200469(1982)039<0722:CERTML>2.0.CO;2 (1982).

47 Neelin, J. D., Peters, O. \& Hales, K. The Transition to Strong Convection. J Atmos Sci 66, 2367-2384, doi:10.1175/2009JAS2962.1 (2009).

48 Kalnay, E., Mo, K. C. \& Paegle, J. Large-Amplitude, Short-Scale Stationary Rossby Waves in the Southern-Hemisphere - Observations and Mechanistic Experiments to Determine Their Origin. J Atmos Sci 43, 252-275, doi:10.1175/15200469(1986)043<0252:Lasssr>2.0.Co;2 (1986).

49 Wheeler, M. C. \& Hendon, H. H. An all-season real-time multivariate MJO index: Development of an index for monitoring and prediction. Mon Weather Rev 132, 19171932, doi:10.1175/1520-0493(2004)132<1917:Aarmmi>2.0.Co;2 (2004).

50 McPhaden, M. J., Zebiak, S. E. \& Glantz, M. H. ENSO as an integrating concept in Earth science. Science 314, 1740-1745, doi:10.1126/science.1132588 (2006). 
51 Philander, S. G. H. El Niño Southern Oscillation phenomena. Nature 302, 295-301, doi:10.1038/302295a0 (1983).

52 Trenberth, K. E. \& Shea, D. J. On the Evolution of the Southern Oscillation. Mon Weather Rev 115, 3078-3096, doi:Doi 10.1175/15200493(1987)115<3078:Oteots>2.0.Co;2 (1987).

53 van Loon, H. \& Shea, D. J. The Southern Oscillation .6. Anomalies of Sea-Level Pressure on the Southern-Hemisphere and of Pacific Sea-Surface Temperature during the Development of a Warm Event. Mon Weather Rev 115, 370-379, doi:Doi 10.1175/1520-0493(1987)115<0370:Tsopva>2.0.Co;2 (1987).

54 Santoso, A., McPhaden, M. J. \& Cai, W. The Defining Characteristics of ENSO Extremes and the Strong 2015/2016 El Niño. Reviews of Geophysics 55, 1079-1129, doi:10.1002/2017RG000560 (2017).

55 Borlace, S., Santoso, A., Cai, W. J. \& Collins, M. Extreme swings of the South Pacific Convergence Zone and the different types of El Nino events. Geophys Res Lett 41, 4695-4703, doi:10.1002/2014g1060551 (2014).

56 Schneider, T., Bischoff, T. \& Haug, G. H. Migrations and dynamics of the intertropical convergence zone. Nature 513, 45-53, doi:10.1038/nature13636 (2014).

57 Richey, J. N. \& Sachs, J. P. Precipitation changes in the western tropical Pacific over the past millennium. Geology 44, 671-674, doi:10.1130/G37822.1 (2016).

58 Donohoe, A., Marshall, J., Ferreira, D. \& McGee, D. The Relationship between ITCZ Location and Cross-Equatorial Atmospheric Heat Transport: From the Seasonal Cycle to the Last Glacial Maximum. J Climate 26, 3597-3618, doi:10.1175/JCLI-D-1200467.1 (2012).

59 Trenberth, K. E., Caron, J. M., Stepaniak, D. P. \& Worley, S. Evolution of El NiñoSouthern Oscillation and global atmospheric surface temperatures. Journal of Geophysical Research: Atmospheres 107, AAC 5-1-AAC 5-17 (2002).

60 Gouriou, Y. \& Delcroix, T. Seasonal and ENSO variations of sea surface salinity and temperature in the South Pacific Convergence Zone during 1976-2000. J Geophys Res-Oceans 107, doi:10.1029/2001jc000830 (2002).

61 Ganachaud, A. et al. The Southwest Pacific Ocean circulation and climate experiment (SPICE). Journal of Geophysical Research: Oceans 119, 7660-7686, doi:10.1002/2013jc009678 (2014).

62 Dassie, E. P., Hasson, A., Khodri, M., Lebas, N. \& Linsley, B. K. Spatiotemporal Variability of the South Pacific Convergence Zone Fresh Pool Eastern Front from Coral-Derived Surface Salinity Data. J Climate 31, 3265-3288, doi:10.1175/Jcli-D17-0071.1 (2018).

63 Tangri, N., Dunbar, R. B., Linsley, B. K. \& Mucciarone, D. M. ENSO's Shrinking Twentieth-Century Footprint Revealed in a Half-Millennium Coral Core From the South Pacific Convergence Zone. Paleoceanogr Paleocl 33, 1136-1150, doi:10.1029/2017pa003310 (2018).

64 Juillet-Leclerc, A. et al. SPCZ migration and ENSO events during the 20th century as revealed by climate proxies from a Fiji coral. Geophys Res Lett 33, doi:10.1029/2006gl025950 (2006).

65 Gorman, M. K. et al. A coral-based reconstruction of sea surface salinity at Sabine Bank, Vanuatu from 1842 to 2007 CE. Paleoceanography 27, doi:10.1029/2012pa002302 (2012).

66 Kilbourne, K. H., Quinn, T. M., Taylor, F. W., Delcroix, T. \& Gouriou, Y. El NinoSouthern Oscillation-related salinity variations recorded in the skeletal geochemistry of a Porites coral from Espiritu Santo, Vanuatu. Paleoceanography 19, doi:10.1029/2004pa001033 (2004). 
67 Le Bec, N., Juillet-Leclerc, A., Correge, T., Blamart, D. \& Delcroix, T. A coral delta O-18 record of ENSO driven sea surface salinity variability in Fiji (south-western tropical Pacific). Geophys Res Lett 27, 3897-3900, doi:Doi 10.1029/2000gl011843 (2000).

68 Linsley, B. K., R. B. Dunbar, D. Lee, N. Tangri, E. P, Dassié Abrupt Northward Shift of SPCZ position in the late-1920s Indicates Coordinated Atlantic and Pacific ITCZ Change. Past Global Changes Magazine 25, 5, doi:doi: 10.22498/pages.25.1.52 (2017).

69 Power, S., Casey, T., Folland, C., Colman, A. \& Mehta, V. Inter-decadal modulation of the impact of ENSO on Australia. Clim Dynam 15, 319-324, doi:DOI 10.1007/s003820050284 (1999).

70 Newman, M. et al. The Pacific Decadal Oscillation, Revisited. J Climate 29, 43994427, doi:10.1175/JCLI-D-15-0508.1 (2016).

71 Deser, C., Phillips, A. S. \& Hurrell, J. W. Pacific interdecadal climate variability: Linkages between the tropics and the North Pacific during boreal winter since 1900. $J$ Climate 17, 3109-3124, doi:Doi 10.1175/1520-0442(2004)017<3109:Picvlb>2.0.Co;2 (2004).

72 Compo, G. P. et al. The Twentieth Century Reanalysis Project. Q J Roy Meteor Soc 137, 1-28, doi:10.1002/qj.776 (2011).

73 Bagnato, S., Linsley, B. K., Howe, S. S. \& Wellington, G. M. Coral oxygen isotope records of interdecadal climate variations in the South Pacific Convergence Zone region. Geochem Geophy Geosy 6, doi:10.1029/2004gc000879 (2005).

74 Maupin, C. R. et al. Persistent decadal-scale rainfall variability in the tropical South Pacific Convergence Zone through the past six centuries. Clim Past 10, 1319-1332, doi:10.5194/cp-10-1319-2014 (2014).

75 Sinclair, D. J. et al. Response of the South Pacific Convergence Zone to Rapid Glacial Climate Changes. Nat Geosci (in review).

76 Murphy, B. F., Power, S. B. \& McGree, S. The Varied Impacts of El Nino-Southern Oscillation on Pacific Island Climates. J Climate 27, 4015-4036, doi:10.1175/Jcli-D13-00130.1 (2014).

77 Griffiths, G. M., Salinger, M. J. \& Leleu, I. Trends in extreme daily rainfall across the South Pacific and relationship to the South Pacific Convergence Zone. Int J Climatol 23, 847-869, doi:10.1002/joc.923 (2003).

78 Greene, J. S., Paris, B. \& Morrissey, M. Historical changes in extreme precipitation events in the tropical Pacific region. Clim Res 34, 1-14 (2007).

79 McGree, S. et al. An updated assessment of trends and variability in total and extreme rainfall in the western Pacific. Int J Climatol 34, 2775-2791, doi:10.1002/joc.3874 (2014).

80 Widlansky, M. J., Timmermann, A., McGregor, S., Stuecker, M. F. \& Cai, W. J. An Interhemispheric Tropical Sea Level Seesaw due to El Nino Taimasa. J Climate 27, 1070-1081, doi:10.1175/Jcli-D-13-00276.1 (2014).

81 Bank, W. Not if, but when: Adapting to natural hazards in the Pacific Island Region, A policy note., (Washington D.C., 2006).

82 Magee, A. D., Verdon-Kidd, D. C., Kiem, A. S. \& Royle, S. A. Tropical cyclone perceptions, impacts and adaptation in the Southwest Pacific: an urban perspective from Fiji, Vanuatu and Tonga. Nat. Hazards Earth Syst. Sci. 16, 1091-1105, doi:10.5194/nhess-16-1091-2016 (2016).

83 Jourdain, N. C. et al. Mesoscale Simulation of Tropical Cyclones in the South Pacific: Climatology and Interannual Variability. J Climate 24, 3-25, doi:10.1175/2010jcli3559.1 (2011). 
940

941

942

943

944

945

946

947

948

949

950

951

952

953

954

955

956

957

958

959

960

961

962

963

964

965

966

967

968

969

970

971

972

973

974

975

976
84 Menkes, C. E. et al. Comparison of tropical cyclogenesis indices on seasonal to interannual timescales. Clim Dynam 38, 301-321, doi:10.1007/s00382-011-1126-x (2012).

85 Widlansky, M. J. et al. Tropical Cyclone Projections: Changing Climate Threats for Pacific Island Defense Installations. Weather Clim Soc 11, 3-15, doi:10.1175/WcasD-17-0112.1 (2019).

86 Basher, R. E. \& Zheng, X. Tropical Cyclones in the Southwest Pacific - Spatial Patterns and Relationships to Southern-Oscillation and Sea-Surface Temperature. $J$ Climate 8, 1249-1260, doi:10.1175/1520-0442(1995)008<1249:Tcitsp>2.0.Co;2 (1995).

87 Kuleshov, Y., Qi, L., Fawcett, R. \& Jones, D. On tropical cyclone activity in the Southern Hemisphere: Trends and the ENSO connection. Geophys Res Lett 35, doi:10.1029/2007g1032983 (2008).

88 Ramsay, H. A., Leslie, L. M., Lamb, P. J., Richman, M. B. \& Leplastrier, M. Interannual variability of tropical cyclones in the Australian region: Role of largescale environment. J Climate 21, 1083-1103, doi:10.1175/2007jcli1970.1 (2008).

89 Chand, S. S., McBride, J. L., Tory, K. J., Wheeler, M. C. \& Walsh, K. J. E. Impact of Different ENSO Regimes on Southwest Pacific Tropical Cyclones. J Climate 26, 600608, doi:10.1175/Jcli-D-12-00114.1 (2013).

90 Larrue, S. \& Chiron, T. Les îles de Polynésie française face à l'aléa cyclonique. [VertigO] La revue électronique en sciences de l'environnement 10, 0-0 (2010).

91 Chappel, L. \& Bate, P. The South Pacific and southeast Indian Ocean tropical cyclone season 1997-98. Australian Meteorological Magazine 49, 121-138 (2000).

92 Timmermann, A., McGregor, S. \& Jin, F.-F. Wind Effects on Past and Future Regional Sea Level Trends in the Southern Indo-Pacific. J Climate 23, 4429-4437, doi:10.1175/2010JCLI3519.1 (2010).

93 Delcroix, T. Observed surface oceanic and atmospheric variability in the tropical Pacific at seasonal and ENSO timescales: A tentative overview. J Geophys ResOceans 103, 18611-18633, doi:Doi 10.1029/98jc00814 (1998).

94 Widlansky, M. J., Timmermann, A. \& Cai, W. J. Future extreme sea level seesaws in the tropical Pacific. Sci Adv 1, doi:10.1126/sciadv.1500560 (2015).

95 Raymundo, L. J., Burdick, D., Lapacek, V. A., Miller, R. \& Brown, V. Anomalous temperatures and extreme tides: Guam staghorn Acropora succumb to a double threat. Marine Ecology Progress Series 564, 47-55 (2017).

96 Lovelock, C. E., Feller, I. C., Reef, R., Hickey, S. \& Ball, M. C. Mangrove dieback during fluctuating sea levels. Scientific Reports 7, 1680, doi:10.1038/s41598-01701927-6 (2017).

97 Becker, M. et al. Sea level variations at tropical Pacific islands since 1950. Global and Planetary Change 80, 85-98 (2012).

98 Han, S.-C., Sauber, J., Pollitz, F. \& Ray, R. Sea Level Rise in the Samoan Islands Escalated by Viscoelastic Relaxation After the 2009 Samoa-Tonga Earthquake. Journal of Geophysical Research: Solid Earth 124, 4142-4156, doi:10.1029/2018jb017110 (2019).

99 Widlansky, M. J. et al. Multimodel Ensemble Sea Level Forecasts for Tropical Pacific Islands. Journal of Applied Meteorology and Climatology 56, 849-862, doi:10.1175/JAMC-D-16-0284.1 (2017).

100 Garreaud, R. \& Aceituno, P. Interannual Rainfall Variability over the South American Altiplano. J Climate 14, 2779-2789, doi:10.1175/15200442(2001)014<2779:IRVOTS>2.0.CO;2 (2001). 
101 Vuille, M. \& Keimig, F. Interannual Variability of Summertime Convective Cloudiness and Precipitation in the Central Andes Derived from ISCCP-B3 Data. $J$ Climate 17, 3334-3348, doi:10.1175/1520-0442(2004)017<3334:IVOSCC>2.0.CO;2 (2004).

102 Sulca, J., Takahashi, K., Espinoza, J.-C., Vuille, M. \& Lavado-Casimiro, W. Impacts of different ENSO flavors and tropical Pacific convection variability (ITCZ, SPCZ) on austral summer rainfall in South America, with a focus on Peru. Int J Climatol 38, 420-435, doi:10.1002/joc.5185 (2018).

103 Sulca, J., Vuille, M., Silva, Y. \& Takahashi, K. Teleconnections between the Peruvian Central Andes and Northeast Brazil during Extreme Rainfall Events in Austral Summer. Journal of Hydrometeorology 17, 499-515, doi:10.1175/JHM-D-15-0034.1 (2016).

104 Grimm, A. M. \& Silva Dias, P. L. Analysis of Tropical-Extratropical Interactions with Influence Functions of a Barotropic Model. J Atmos Sci 52, 3538-3555, doi:10.1175/1520-0469(1995)052<3538:AOTIWI>2.0.CO;2 (1995).

105 Liebmann, B., Kiladis, G. N., Marengo, J., Ambrizzi, T. \& Glick, J. D. Submonthly Convective Variability over South America and the South Atlantic Convergence Zone. J Climate 12, 1877-1891, doi:10.1175/15200442(1999)012<1877:SCVOSA>2.0.CO;2 (1999).

106 Vera, C., Silvestri, G., Barros, V. \& Carril, A. Differences in El Niño Response over the Southern Hemisphere. J Climate 17, 1741-1753, doi:10.1175/15200442(2004)017<1741:DIENRO>2.0.CO;2 (2004).

107 Clem, K. R. \& Renwick, J. A. Austral Spring Southern Hemisphere Circulation and Temperature Changes and Links to the SPCZ. J Climate 28, 7371-7384, doi:10.1175/Jcli-D-15-0125.1 (2015).

108 Clem, K. R., Lintner, B. R., Broccoli, A. J. \& Miller, J. R. Role of the South Pacific Convergence Zone in West Antarctic Decadal Climate Variability. Geophys Res Lett 46, 6900-6909, doi:10.1029/2019g1082108 (2019).

109 Held, I. M. \& Soden, B. J. Robust responses of the hydrological cycle to global warming. J Climate 19, 5686-5699, doi:Doi 10.1175/Jcli3990.1 (2006).

110 Christensen, J. H. et al. Climate Phenomena and their Relevance for Future Regional Climate Change. Climate Change 2013: The Physical Science Basis, 1217-1308 (2014).

111 Xie, S.-P. et al. Global warming pattern formation: Sea surface temperature and rainfall. J Climate 23, 966-986 (2010).

112 Chadwick, R., Boutle, I. \& Martin, G. Spatial patterns of precipitation change in CMIP5: Why the rich do not get richer in the tropics. J Climate 26, 3803-3822 (2013).

113 Collins, M. et al. Long-term Climate Change: Projections, Commitments and Irreversibility. Climate Change 2013: The Physical Science Basis, 1029-1136 (2014).

114 Power, S., Delage, F., Chung, C., Kociuba, G. \& Keay, K. Robust twenty-firstcentury projections of El Nino and related precipitation variability. Nature 502, 541545, doi:10.1038/nature12580 (2013).

115 McGree, S. et al. Recent Changes in Mean and Extreme Temperature and Precipitation in the Western Pacific Islands. J Climate 32, 4919-4941, doi:10.1175/Jcli-D-18-0748.1 (2019).

116 Salinger, M. J., McGree, S., Beucher, F., Power, S. B. \& Delage, F. A new index for variations in the position of the South Pacific convergence zone 1910/11-2011/2012. Clim Dynam 43, 881-892, doi:10.1007/s00382-013-2035-y (2014). 
117 Meehl, G. A. et al. THE WCRP CMIP3 Multimodel Dataset: A New Era in Climate Change Research. B Am Meteorol Soc 88, 1383-1394, doi:10.1175/BAMS-88-9-1383 (2007).

118 Taylor, K. E., Stouffer, R. J. \& Meehl, G. A. An Overview of CMIP5 and the Experiment Design. B Am Meteorol Soc 93, 485-498, doi:10.1175/BAMS-D-1100094.1 (2012).

119 Eyring, V. et al. Overview of the Coupled Model Intercomparison Project Phase 6 (CMIP6) experimental design and organization. Geosci. Model Dev. 9, 1937-1958, doi:10.5194/gmd-9-1937-2016 (2016).

120 Bellenger, H., Guilyardi, E., Leloup, J., Lengaigne, M. \& Vialard, J. ENSO representation in climate models: from CMIP3 to CMIP5. Clim Dynam 42, 19992018, doi:10.1007/s00382-013-1783-z (2014).

121 Grose, M. R. et al. Assessment of the CMIP5 global climate model simulations of the western tropical Pacific climate system and comparison to CMIP3. Int J Climatol 34, 3382-3399, doi:10.1002/joc.3916 (2014).

122 Li, G. \& Xie, S.-P. Tropical Biases in CMIP5 Multimodel Ensemble: The Excessive Equatorial Pacific Cold Tongue and Double ITCZ Problems. J Climate 27, 17651780, doi:10.1175/JCLI-D-13-00337.1 (2014).

123 Brown, J. N., Matear, R. J., Brown, J. R. \& Katzfey, J. Precipitation projections in the tropical Pacific are sensitive to different types of SST bias adjustment. Geophys Res Lett 42, 10856-10866, doi:10.1002/2015gl066184 (2015).

124 Ham, Y.-G. \& Kug, J.-S. ENSO amplitude changes due to greenhouse warming in CMIP5: Role of mean tropical precipitation in the twentieth century. Geophys Res Lett 43, 422-430, doi:10.1002/2015GL066864 (2016).

125 Collins, M. et al. The impact of global warming on the tropical Pacific ocean and El Nino. Nat Geosci 3, 391-397, doi:10.1038/Ngeo868 (2010).

126 Cai, W. et al. ENSO and greenhouse warming. Nat Clim Change 5, 849, doi:10.1038/nclimate2743 (2015).

127 Watanabe, M., Kamae, Y. \& Kimoto, M. Robust increase of the equatorial Pacific rainfall and its variability in a warmed climate. Geophys Res Lett 41, 3227-3232, doi:10.1002/2014gl059692 (2014).

128 Li, G., Xie, S. P., Du, Y. \& Luo, Y. Y. Effects of excessive equatorial cold tongue bias on the projections of tropical Pacific climate change. Part I: the warming pattern in CMIP5 multi-model ensemble. Clim Dynam 47, 3817-3831, doi:10.1007/s00382016-3043-5 (2016).

129 Cai, W. et al. Increasing frequency of extreme El Niño events due to greenhouse warming. Nat Clim Change 4, 111, doi:10.1038/nclimate2100 (2014).

130 Chung, C. T. Y. \& Power, S. B. Modelled Rainfall Response to Strong El Nino Sea Surface Temperature Anomalies in the Tropical Pacific. J Climate 28, 3133-3151, doi:10.1175/Jcli-D-14-00610.1 (2015).

131 Capotondi, A. et al. Understanding ENSO Diversity. B Am Meteorol Soc 96, 921-938, doi:10.1175/Bams-D-13-00117.1 (2015).

132 Emile-Geay, J. et al. A global multiproxy database for temperature reconstructions of the Common Era. Scientific Data 4, 170088, doi:10.1038/sdata.2017.88 (2017).

133 Saint-Lu, M., Braconnot, P., Leloup, J., Lengaigne, M. \& Marti, O. Changes in the ENSO/SPCZ relationship from past to future climates. Earth Planet Sc Lett 412, 1824, doi:10.1016/j.epsl.2014.12.033 (2015).

134 Zhou, Z.-Q. \& Xie, S.-P. Effects of Climatological Model Biases on the Projection of Tropical Climate Change. J Climate 28, 9909-9917, doi:10.1175/JCLI-D-15-0243.1 (2015). 
135 Lintner, B. R. et al. Characterizing CMIP5 model spread in simulated rainfall in the Pacific Intertropical Convergence and South Pacific Convergence Zones. J Geophys Res-Atmos 121, 11590-11607, doi:10.1002/2016jd025284 (2016).

136 Niznik, M. J. \& Lintner, B. R. Circulation, Moisture, and Precipitation Relationships along the South Pacific Convergence Zone in Reanalyses and CMIP5 Models. $J$ Climate 26, 10174-10192, doi:10.1175/Jcli-D-13-00263.1 (2013).

137 Xie, P. \& Arkin, P. A. Global Precipitation: A 17-Year Monthly Analysis Based on Gauge Observations, Satellite Estimates, and Numerical Model Outputs. B Am Meteorol Soc 78, 2539-2558, doi:10.1175/15200477(1997)078<2539:GPAYMA>2.0.CO;2 (1997).

138 Kanamitsu, M. et al. NCEP-DOE AMIP-II Reanalysis (R-2). B Am Meteorol Soc 83, 1631-1644, doi:10.1175/BAMS-83-11-1631 (2002).

139 Huang, B. et al. Extended Reconstructed Sea Surface Temperature, Version 5 (ERSSTv5): Upgrades, Validations, and Intercomparisons. J Climate 30, 8179-8205, doi:10.1175/JCLI-D-16-0836.1 (2017).

140 Knapp, K. R., Kruk, M. C., Levinson, D. H., Diamond, H. J. \& Neumann, C. J. The International Best Track Archive for Climate Stewardship (IBTrACS). B Am Meteorol Soc 91, 363-376, doi:10.1175/2009BAMS2755.1 (2010).

141 Le Traon, P. Y. et al. From Observation to Information and Users: The Copernicus Marine Service Perspective. Frontiers in Marine Science 6, doi:10.3389/fmars.2019.00234 (2019).

142 Caldwell, P. C., Merrifield, M. A. \& Thompson, P. R. in The Joint Archive for Sea Level holdings NCEI Accession 0019568 (NOAA National Centers for Environmental Information, 2015).

143 Huffman, G. J. et al. The Global Precipitation Climatology Project (GPCP) Combined Precipitation Dataset. B Am Meteorol Soc 78, 5-20, doi:10.1175/15200477(1997)078<0005:TGPCPG>2.0.CO;2 (1997).

\section{Figures}


(a) DJF precipitation ( $\mathrm{mm} /$ day) and $925 \mathrm{hPa}$ wind $(\mathrm{m} / \mathrm{s})$

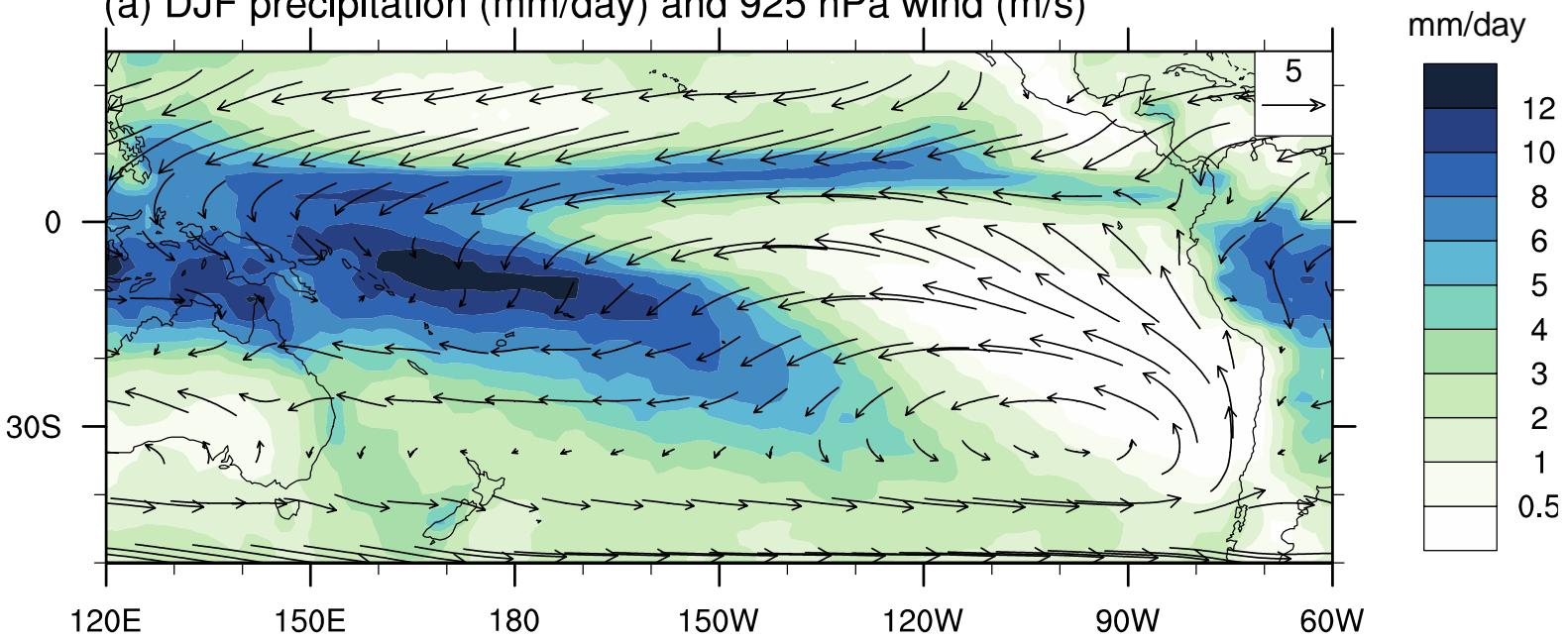

(b) DJF sea surface temperature $(\mathrm{C})$ and mean sea level pressure $(\mathrm{hPa})$

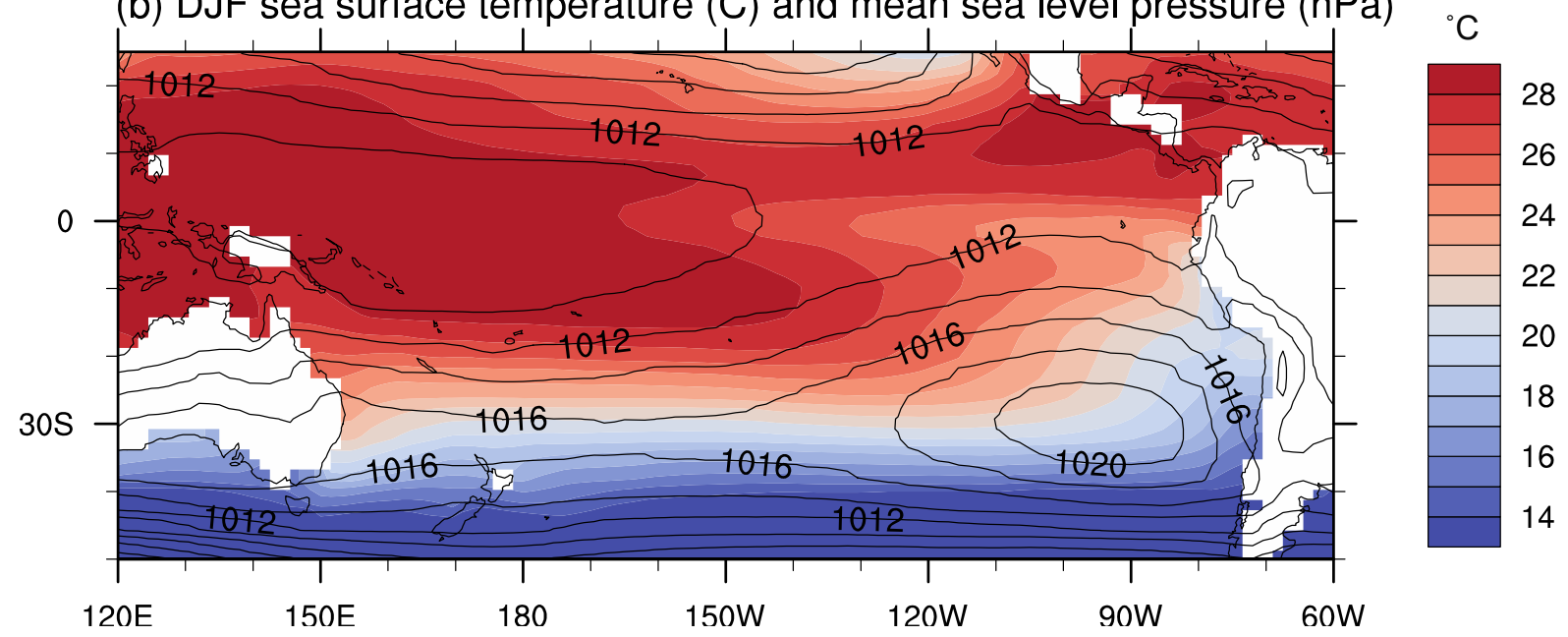

1107

1108 Figure 1: Climatology of the South Pacific. December to February a CMAP ${ }^{137}$ precipitation (mm/day,

1109 colors) and NCEP2 ${ }^{138} 925 \mathrm{hPa}$ winds ( $\mathrm{m} / \mathrm{s}$, vectors), and b ERSSTv5 ${ }^{139}$ sea surface temperature $\left({ }^{\circ} \mathrm{C}\right.$,

1110 colors) and NCEP2 ${ }^{138}$ mean sea level pressure (hPa, contour lines) averaged over 1980-2005.

1111

1112

1113

1114

1115

1116 
(a)

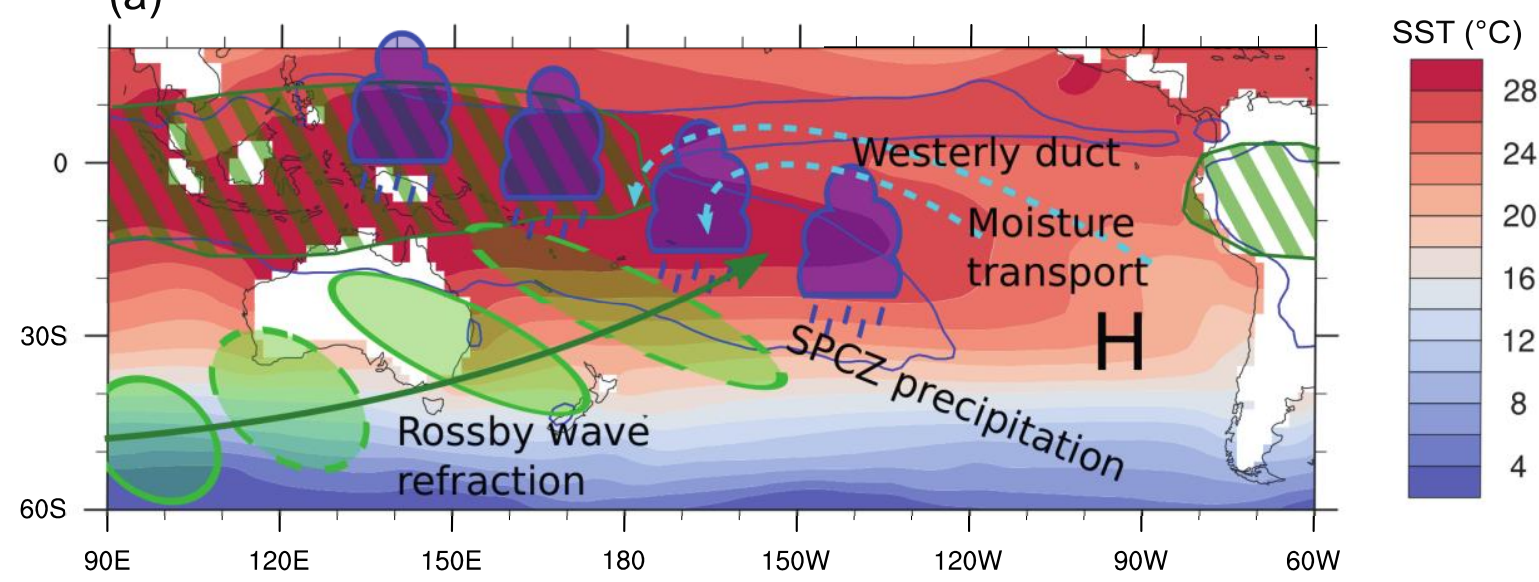

(b)

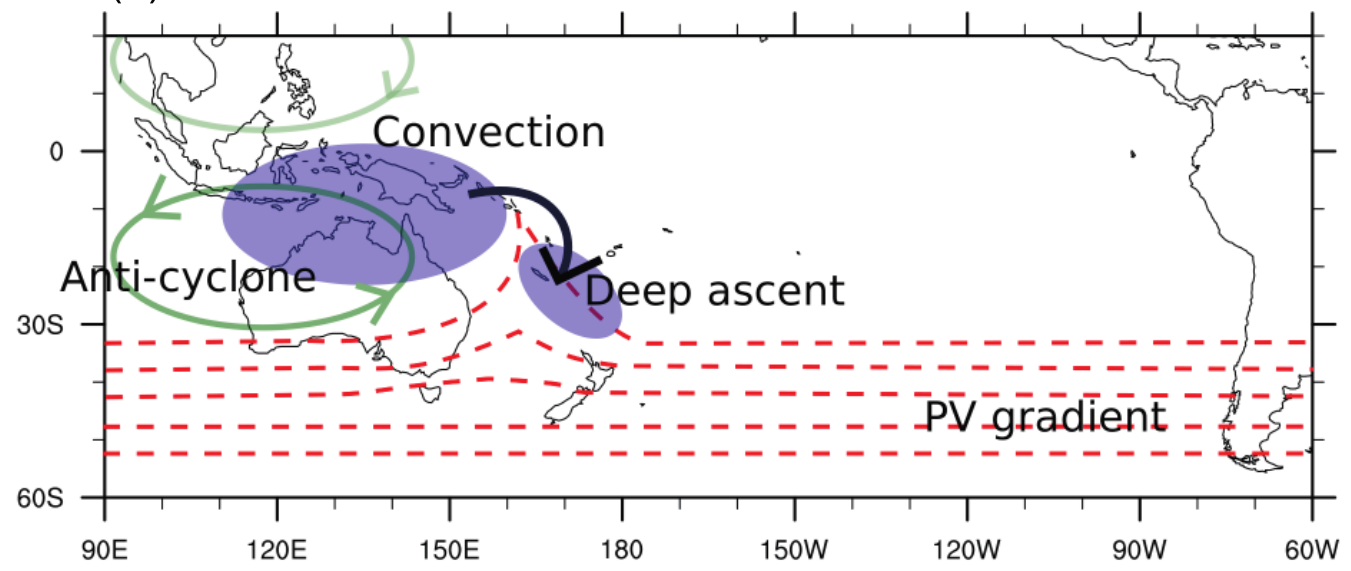

1119 Figure 2: Mechanisms for formation of the diagonal SPCZ. (a) Extratropical-tropical interaction:

1120 the zonally asymmetric SST distribution generates a subtropical anticyclone over the southeast Pacific,

1121 which results in southwestward moisture transport into the SPCZ region. Dynamical forcing from

1122 equatorward propagating Rossby waves triggers convection in a northwest-southeast oriented band

1123 forming the diagonal SPCZ. Moisture is supplied at low levels from surface evaporation and advection

1124 around the eastern Pacific subtropical high [Adapted from refs. ${ }^{29,31}$ ]. (b) Direct forcing by tropical

1125 convection: convection over the Maritime Continent forces an equatorial Rossby wave response with 1126 an upper-tropospheric anticyclone. On its eastern flank, this advects large magnitude potential vorticity 1127 (PV) equatorward, from the PV reservoir associated with the subtropical jet. The PV anomaly 1128 destabilises the atmosphere and leads to deep convection along the SPCZ [Adapted from refs. ${ }^{34,44}$ ]. 

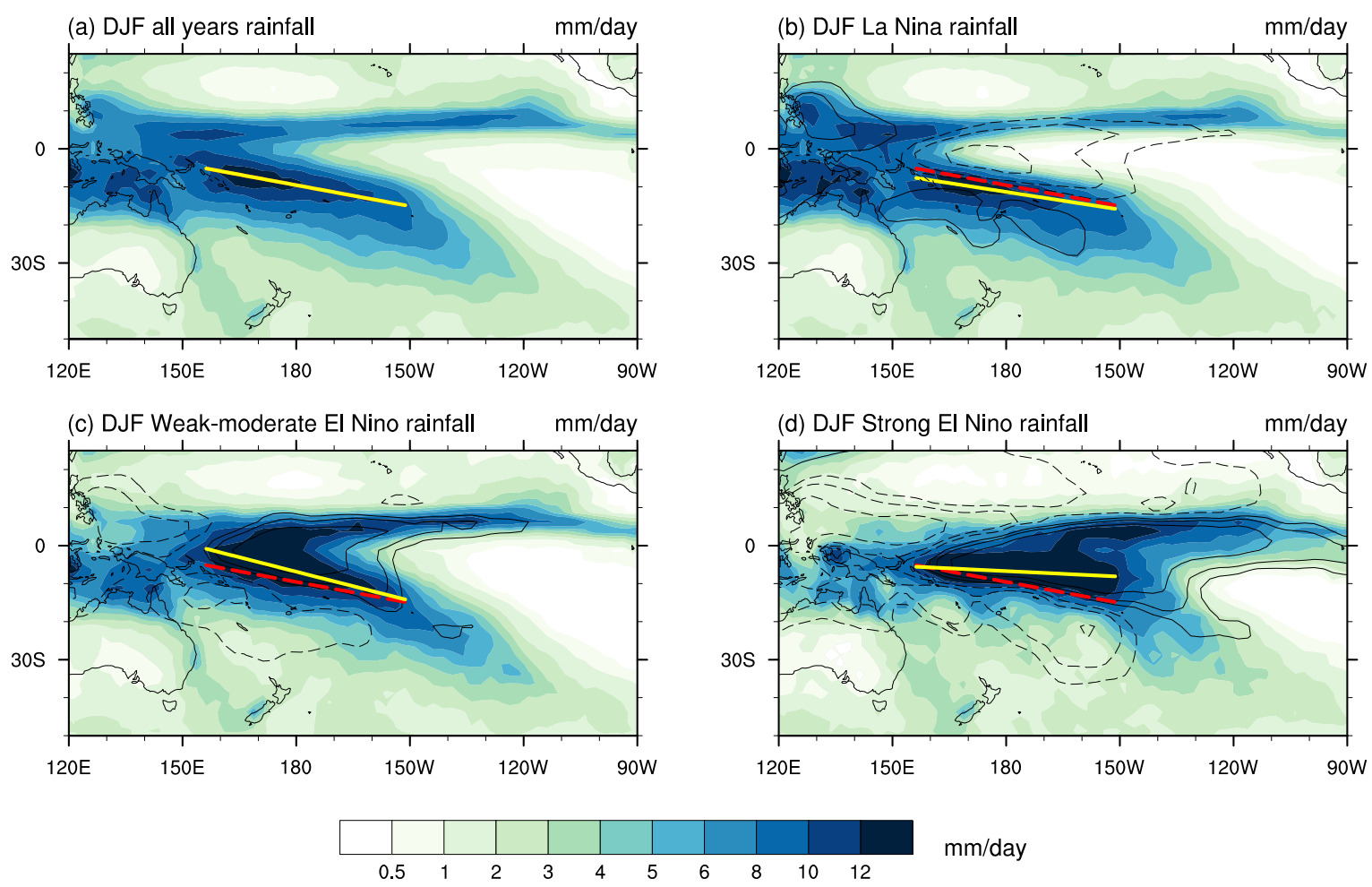

1131 Figure 3: Displacement of the SPCZ in response to ENSO. Mean December to February SPCZ

1132 position in: a all years, $\mathbf{b}$ La Niña years, $\mathbf{c}$ weak to moderate El Niño years, and $\mathbf{d}$ strong El Niño years

1133 (1979-2018) using CMAP ${ }^{137}$ precipitation and NINO3 SST from ERSSTv5 ${ }^{139}$ to classify events. Weak-

1134 moderate El Niño is NINO3 greater than 0.5 standard deviations and less than 1.5 standard deviations,

1135 La Niña is NINO3 less than -0.5 standard deviations, strong El Niño is NINO3 greater than 1.5 standard

1136 deviations. SPCZ line (yellow) is fitted to the latitude of maximum precipitation at each longitude in

1137 the range $155^{\circ} \mathrm{E}-150^{\circ} \mathrm{W}$ and $0-30^{\circ} \mathrm{S}$. Red dashed line in $\mathbf{b}-\mathbf{d}$ is all year average SPCZ position shown

1138 in a. Contour lines in b-d are rainfall anomaly relative to all year average (levels $=-4,-2,-1,1,2$ and 4 $1139 \mathrm{~mm} /$ day with negative values as dashed lines). 


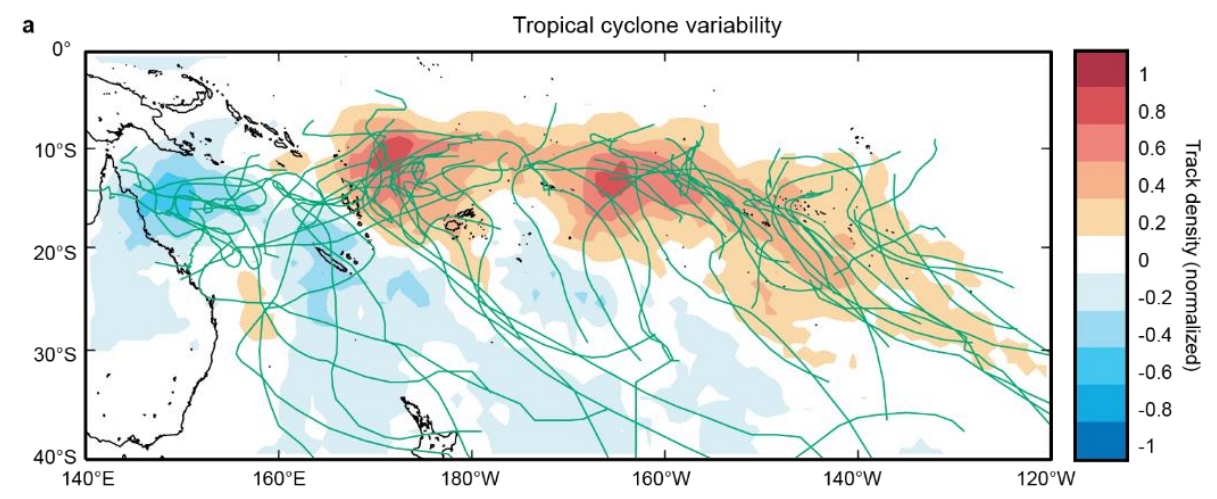

b

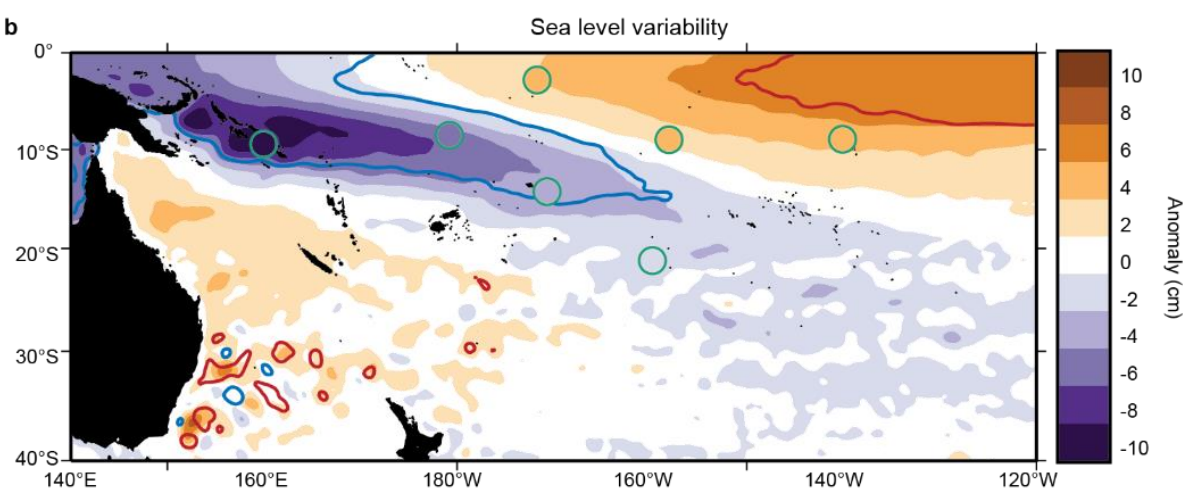

1143 Figure 4: Impacts of SPCZ variability on interannual timescales associated with ENSO. a The

1144 linear regression of the tropical cyclone annual track density (July-June averages) from the IBTrACS ${ }^{140}$ 1145 observational dataset onto the average November-April seasonal Oceanic Nino Index (ONI) during 1146 1979-2016. The tropical cyclone track density is normalized over the map domain for each year. Tracks 1147 during extreme El Niño seasons (corresponding to zonal SPCZ events: 1982/83, 1991/92, 1997/98, and 1148 2015/16) are shown in green. b Satellite and tide-gauge measured sea level variability from the CMEMS 1149 dataset ${ }^{141}$ and Joint Archive for Sea Level holdings ${ }^{142}$, contour and circle shadings respectively. The 1150 linear regression of November-April sea level anomalies onto the seasonal ONI during 1994-2016 is 1151 shown (shading). The average sea level anomaly during 1997/98 and 2015/16 is indicated by the blue $1152(-10 \mathrm{~cm})$ and red $(10 \mathrm{~cm})$ contours. 


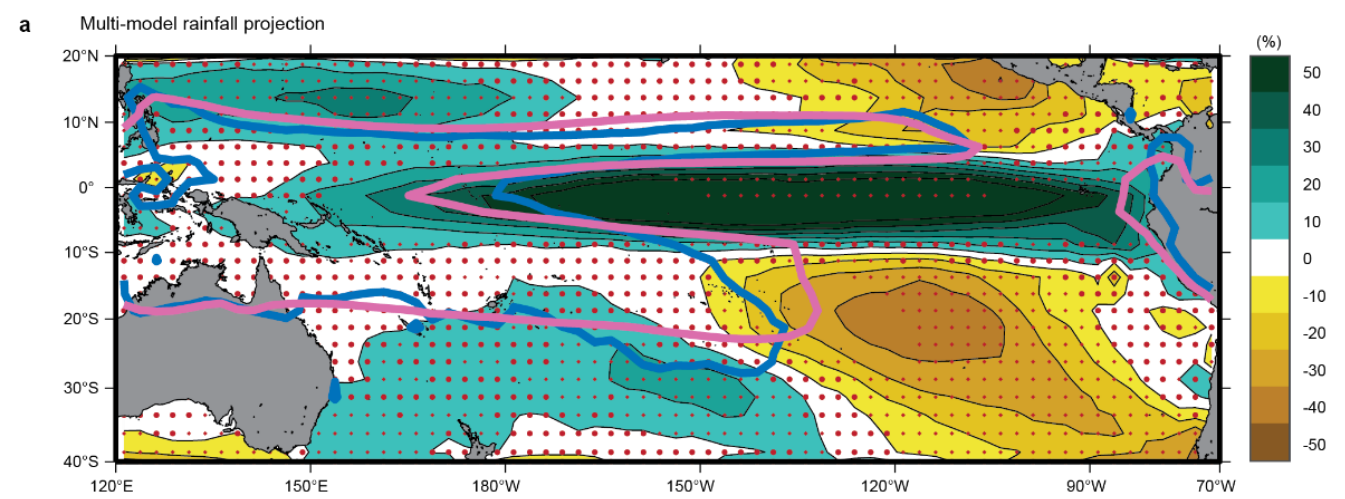

b "Wet gets wetter" response to greenhouse warming

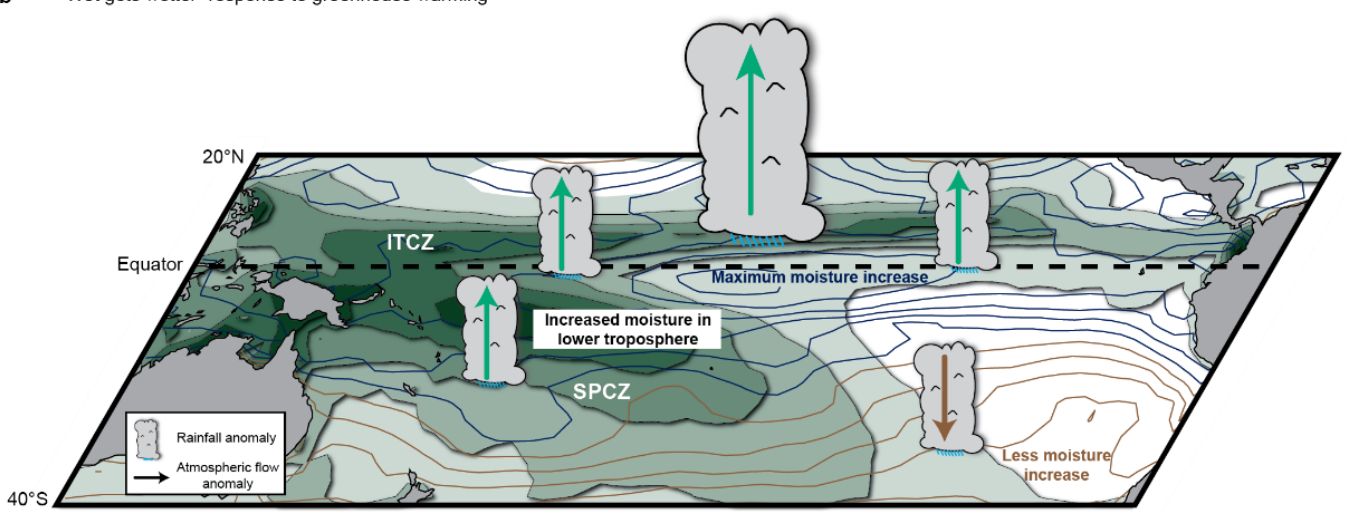

c "Warmest gets wetter" response to greenhouse warming

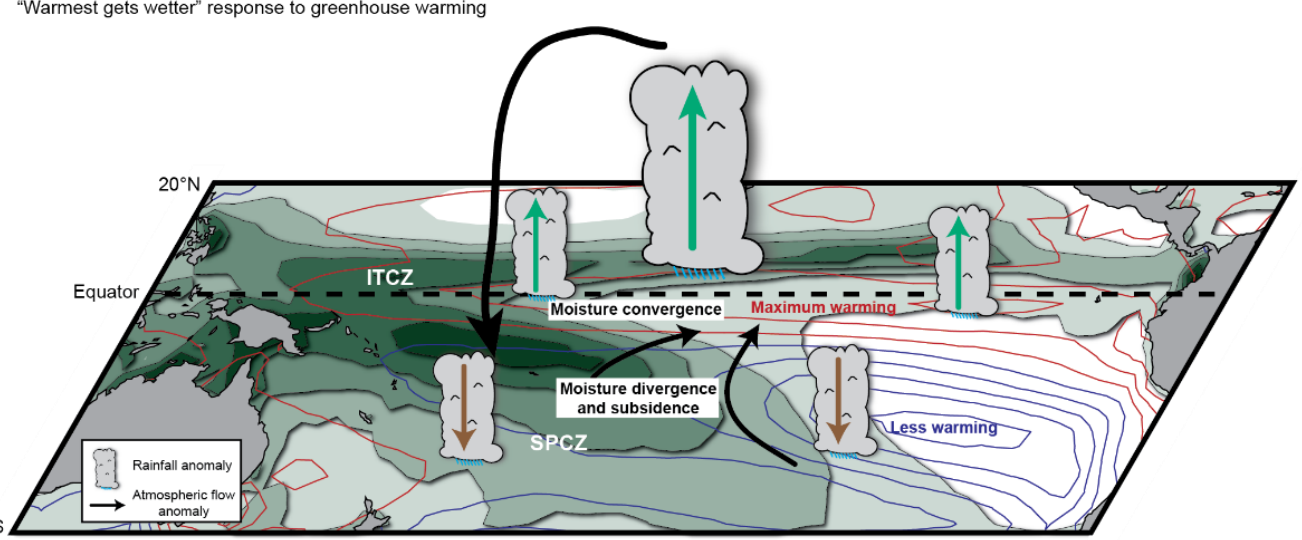

Figure 5: Future change of the SPCZ. a The multi-model rainfall projection from 36 CMIP5 models for the RCP8.5 $\mathrm{W} \mathrm{m}^{-2}$ greenhouse warming scenario during 2075-2100 compared to the historical simulation during 1980-2005. Changes are expressed as percentages compared to the historical rainfall in CMIP5. Stippling indicates regions where less than 2/3 of models agree on the sign of future change

1160 (larger circles) or future change is less than $\pm 1 \mathrm{~mm} \mathrm{day}^{-1}$ (smaller diamonds). The $5 \mathrm{~mm} \mathrm{day}^{-1}$ contours 1161 of mean rainfall observed (blue; GPCP ${ }^{143}$ dataset during 1980-2005) and simulated (magenta; CMIP5 1162 historical during 1980-2005) are outlined. b and $\mathbf{c}$ Illustrations of the thermodynamic (wet gets wetter) 1163 and dynamic (warmest gets wetter) mechanisms affecting the SPCZ rainfall response to greenhouse 1164 warming (adapted from ref. ${ }^{18}$ ). Green and brown arrows indicate a tendency for increased or decreased 1165 rainfall, respectively, associated with either mechanism. Conditions during DJF are shown in all panels. 
(a) Observed CMAP

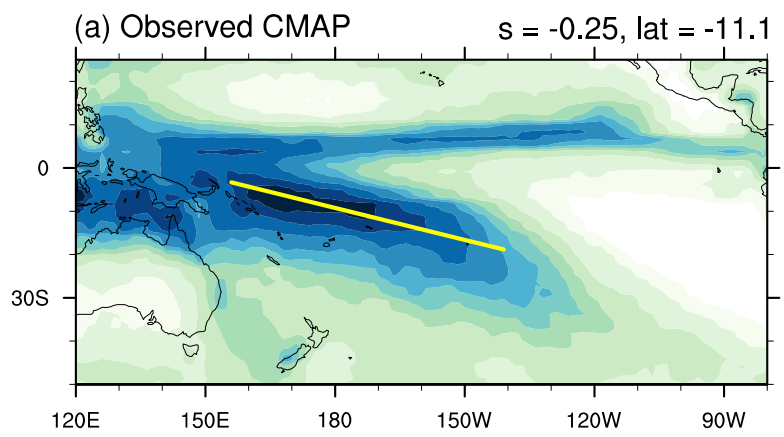

(c) CMIP5 MMM

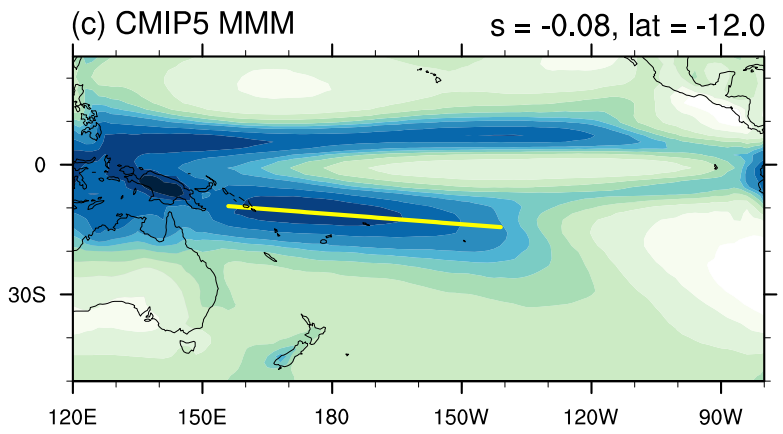

(b) CMIP3 MMM

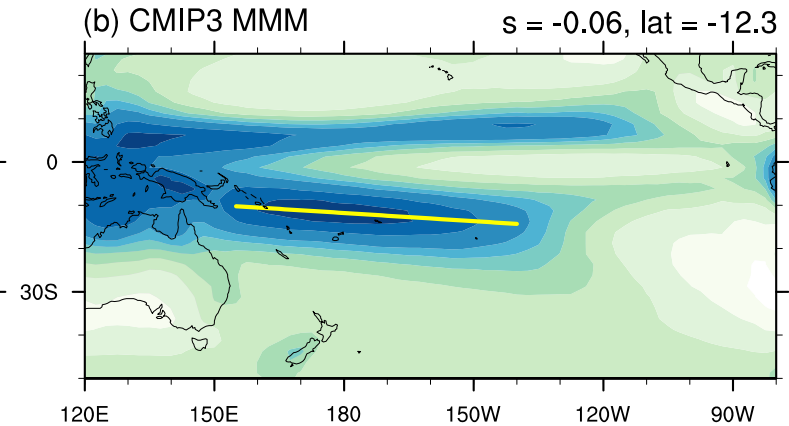

1167
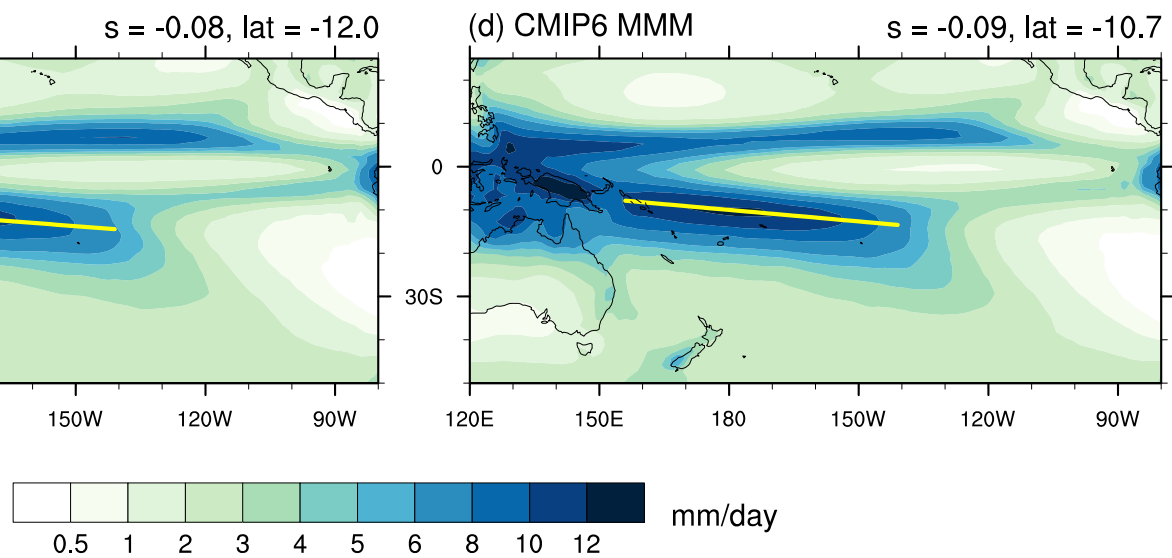

1168 Figure 6: How well do climate models simulate the SPCZ? DJF seasonal average rainfall (mm/day) 1169 for 1980-1999 for a CMAP ${ }^{137}$ observations, b CMIP3 ${ }^{117}$ Multi-Model Mean (MMM) (24 models), c 1170 CMIP5 ${ }^{118}$ MMM (26 models) and d CMIP6 ${ }^{119}$ MMM (27 models). SPCZ line is fitted to the latitude of 1171 maximum precipitation at each longitude in the range $155^{\circ} \mathrm{E}-140^{\circ} \mathrm{W}$ and $0-30^{\circ} \mathrm{S}$. The slope $\left(s,{ }^{\circ} \mathrm{S} /{ }^{\circ} \mathrm{E}\right)$

1172 and mean latitude $\left(l a t,{ }^{\circ} \mathrm{S}\right)$ of the SPCZ line are shown at upper right of each plot. 